\title{
PRINSIP PERANCANGAN MENARD DAN KORELASI EMPIRIS \\ PARAMETER TANAH DENGAN HASIL UJI PRESSUREMETER MENARD
}

\author{
Ibrahim Surya \\ Dosen Biasa, Jurusan Teknik Sipil, Fakultas Teknik, Universitas Kristen Maranatha \\ e-mail: isurya@eng.maranatha.edu
}

\begin{abstract}
ABSTRAK
Dengan semakin bertambahnya pengertian terhadap perilaku tanah, makin disadari perhatian terhadap ketidak-tepatan hasil uji tanah dilaboratorium semakin berkurang. Uji dilapangan (in situ) tidak seperti uji dilaboratorium yang mengakibatkan mengalami akibat dari gangguan cukup besar terhadap contoh tanah. Pada uji dilapangan, dan contoh tanah diuji pada tingkat tegangan efektip yang sesuai, dengan memperhatikan agar gangguan karena memasukkan peralatan kedalam tanah, transportasi contoh tanah diusahakan seminimal mungkin. Uji pressuremeter Menard merupakan suatu alternatif untuk uji tanah in situ guna mendapatkan parameter tanah untuk perancangan bangunan bawah dari suatu bangunan. Dalam tulisan ini dirangkum secara garis besar mengenai pemakaian hasil uji Pressuremeter Menard baik secara langsung atau tidak langsung dalam perancangan geoteknik.
\end{abstract}

Kata kunci: Menard, Empiris, Pressuremeter, Parameter tanah.

\begin{abstract}
As our knowledge of the behaviour of real soils increases, so our appreciation of the inadequacy of conventional laboratory testing grows. The marked consequences of the inevitable disturbance that is caused in any soil specimen, however carefully it has been sampled, transported and reconsolidated in the laboratory, are all too evident. Menard pressuremeter test is an alternative of in situ soil investigation in order to get the soil parameter for geotechnical design of the engineering sub structure of the buildings. In this paper is summarized the application of the results of the Menard pressuremeter test which can be used either directly or indirectly for geotechnical engineering design.
\end{abstract}

Keywords: Menard, Empirical, Pressuremeter, Soil parameter.

\section{PENDAHULUAN}

Tanah adalah material rekayasa yang kompleks dan sifat-sifatnya juga tidak unik atau tetap, malahan bervariasi dengan faktor lingkungan seperti waktu, riwayat tegangan, perubahan muka air tanah dan lain-lain. Karena rumitnya perilaku tanah, korelasi empiris banyak digunakan dalam mengevaluasi parameter tanah. Analisa semua persoalan geoteknik membutuhkan penggunaan model perilaku tanah, lengkap dengan semua sifatsifat tanah yang relevan. Sifat-sifat tanah ini tidak diketahui sebelumnya sehingga perencana perlu mengukur data-data tanah dibawah kondisi yang diamati dalam laboratorium atau dilapangan atau diperkirakan dari data-data tanah dari pengujian yang lain. Perkiraan dibuat seringkali dari percobaan dilaboratorium atau dari pengujian dilapangan, yang dikorelasikan dengan sifat-sifat tanah dengan cara studi korelasi atau 
menghitung kembali dari percobaan dengan skala penuh yang diperoleh dari lapangan. Kebanyakan korelasi dalam literatur yang telah dikembangkan untuk tanah lempung yang tidak sensitip dengan plastisitas rendah sampai sedang dan dengan tanah pasir kuarsa yang dibentuk kembali dilaboratorium. Ekstrapolasi dari korelasi ini terhadap tanah yang "khusus" seperti tanah lempung yang lunak sekali, lempung organik, lempung sensitip, lempung yang berlapis, tanah tersemenkan, pasir kapuran, tanah yang mudah longsor perlu dilakukan dengan sangat hati-hati karena kemungkinan korelasi tadi tidak dapat dipergunakan untuk kondisi tanah yang sudah disebutkan tadi. Jenis-jenis pengujian tanah in situ yang dilakukan secara komersial dapat dilihat pada Tabel 1 dibawah ini disertai dengan parameter yang diukur berikut dengan penggunaannya.

Tabel 1. Pengujian tanah in situ ( Schnaid, 2005).

\begin{tabular}{|c|c|c|c|c|}
\hline Category & Test & Designation & Measurements & Common Applications \\
\hline \multirow{3}{*}{$\begin{array}{l}\text { Non- } \\
\text { destructive } \\
\text { or semi- } \\
\text { destructive } \\
\text { tests }\end{array}$} & $\begin{array}{l}\text { Geophysical tests: } \\
\text { Seismic refraction } \\
\text { Surface waves } \\
\text { Crosshole test } \\
\text { Downhole test }\end{array}$ & $\begin{array}{l}\text { SR } \\
\text { SASW } \\
\text { CHT } \\
\text { DHT }\end{array}$ & $\begin{array}{l}\text { P-waves from surface } \\
\text { R-waves from surface } \\
\text { P \& S waves in boreholes } \\
\text { P \& S waves with depth }\end{array}$ & $\begin{array}{l}\text { Ground characterisation } \\
\text { Small strain stiffness, } G_{\circ}\end{array}$ \\
\hline & $\begin{array}{l}\text { Pressuremeter test } \\
\text { Pre-bored } \\
\text { Self-boring }\end{array}$ & $\begin{array}{l}\text { PMT } \\
\text { SBPM }\end{array}$ & $\begin{array}{l}\mathrm{G},(\psi \times \varepsilon) \text { curve } \\
\mathrm{G},(\psi \times \varepsilon) \text { curve }\end{array}$ & $\begin{array}{l}\text { Shear modulus, G } \\
\text { Shear strength } \\
\text { In situ horizontal stress } \\
\text { Consolidation properties }\end{array}$ \\
\hline & Plate loading test & PLT & $(\mathrm{L} \times \delta)$ curve & Stiffness and strength \\
\hline \multirow{4}{*}{$\begin{array}{l}\text { Invasive } \\
\text { penetration } \\
\text { tests }\end{array}$} & $\begin{array}{l}\text { Cone penetration test } \\
\text { Electric } \\
\text { Piezocone }\end{array}$ & $\begin{array}{l}\text { CPT } \\
\text { CPTU }\end{array}$ & $\begin{array}{l}q_{c}, f_{s} \\
q_{c}, f_{s}, u\end{array}$ & $\begin{array}{l}\text { Soil profiling } \\
\text { Shear strength } \\
\text { Relative density } \\
\text { Consolidation properties }\end{array}$ \\
\hline & $\begin{array}{l}\text { Standard Penetration Test } \\
\text { (energy control) }\end{array}$ & SPT & Penetration ( $\mathrm{N}$ value) & $\begin{array}{l}\text { Soil profiling } \\
\text { Internal friction angle, } \phi^{\prime}\end{array}$ \\
\hline & Flat dilatometer test & DMT & $\mathrm{p}_{0}, \mathrm{p}_{1}$ & $\begin{array}{l}\text { Stiffness } \\
\text { Shear strength }\end{array}$ \\
\hline & Vane shear test & VST & Torque & Undrained shear strength, $s_{u}$ \\
\hline \multirow{4}{*}{$\begin{array}{l}\text { Combined } \\
\text { tests } \\
\text { (Invasive + } \\
\text { Non- } \\
\text { destructive) }\end{array}$} & Cone pressuremeter & CPMT & $\mathrm{q}_{\mathrm{c}}, \mathrm{f}_{\mathrm{s}},(+\mathrm{u}), \mathrm{G},(\psi \times \varepsilon)$ & $\begin{array}{l}\text { Soil profiling } \\
\text { Shear modulus, } \mathrm{G} \\
\text { Shear strength } \\
\text { Consolidation properties }\end{array}$ \\
\hline & Seismic cone & SCPT & $q_{c}, f_{s}, V_{p}, V_{s},(+u)$ & $\begin{array}{l}\text { Soil profiling } \\
\text { Shear strength } \\
\text { Small strain stiffness, } G_{\circ} \\
\text { Consolidation properties }\end{array}$ \\
\hline & Resistivity cone & RCPT & $q_{c}, f_{s}, \rho$ & $\begin{array}{l}\text { Soil profiling } \\
\text { Shear strength } \\
\text { Soil porosity }\end{array}$ \\
\hline & Seismic dilatometer & & $\mathrm{p}_{\mathrm{o}}, \mathrm{p}_{\mathrm{l}}, \mathrm{V}_{\mathrm{p}}, \mathrm{V}_{\mathrm{s}}$ & $\begin{array}{l}\text { Stiffness }\left(G \text { and } G_{o}\right) \\
\text { Shear strength }\end{array}$ \\
\hline
\end{tabular}

Dari uji pressuremeter, parameter tanah yang dihasilkan adalah :

- Modulus geser, $G_{m}$ 
- Modulus pressuremter, $E_{m}$ dihitung dari rumus :

$E_{m}=2 G_{m}(1+v)$

dimana $v=$ rasio Poisson, Menard menggunakan $v=0.33$, sehingga

$E_{m}=2.66 V_{m} \cdot \frac{\Delta p}{\Delta v}$

- Kuat geser tak terdrainasi, $\mathrm{s}_{\mathrm{u}}$

- Tekanan batas (limit pressure), $\mathrm{p}_{\mathrm{L}}$

- Tekanan batas net, $\mathrm{p}_{\mathrm{L}}{ }^{*}=\mathrm{p}_{\mathrm{L}}-\mathrm{p}_{\mathrm{o}}$

- Tekanan rangkak (creep pressure), $\mathrm{p}_{\mathrm{f}}$

- $p_{o}=[z \cdot \gamma-u] K_{o}+u$

dimana : $\mathrm{z}=$ kedalaman dari permukaan tanah sampai ke pertengahan probe

$\mathrm{g}=$ berat volume tanah

$\mathrm{u} \quad=$ tekanan air pori pada kedalaman probe

$\mathrm{K}_{\mathrm{o}}=$ koefisien tekanan tanah dalam keadaan netral

- Tekanan pada titik A adalah $\sigma_{0 H}$, tegangan total horizontal at rest. Koefisien tekanan tanah at rest $\mathrm{K}_{0}$ didapat dari :

$$
K_{0}=\frac{\sigma_{0 H}-u_{0}}{\sigma_{0 V}-u_{0}}
$$

dimana $\sigma_{0 V}$ adalah tegangan total vertikal at rest dan $\mathrm{u}_{0}$ adalah tekanan air pori hidrostatik.

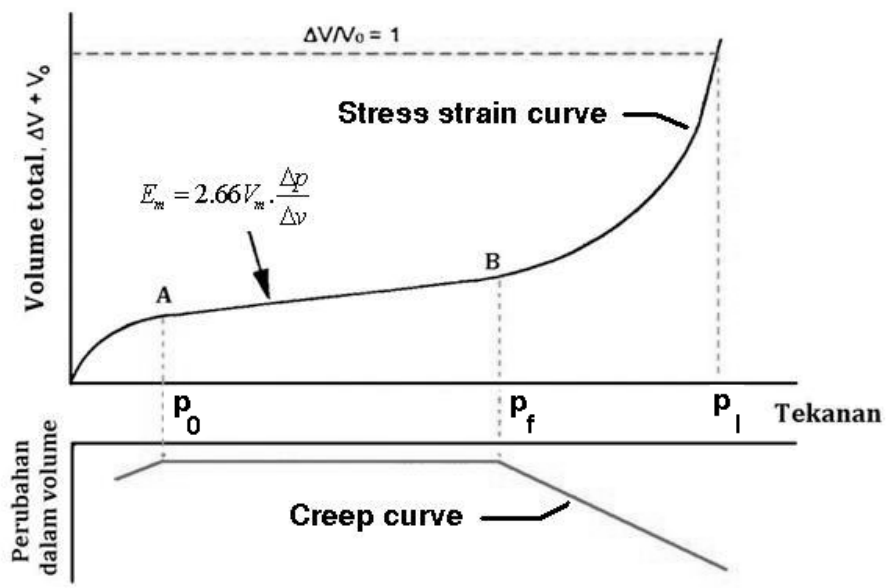

Gambar 1. Kurva tekanan-regangan dan kurva 'rangkak' dari uji pressuremeter (Clarke, 1995). 


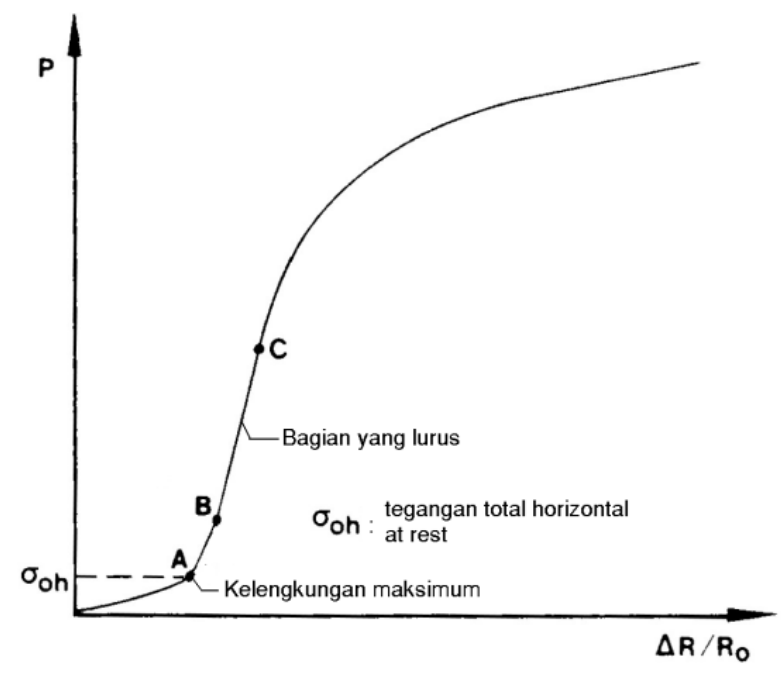

Gambar 2. Mencari tegangan horizontal total at rest (Briaud, 1992).

\section{PRINSIP PERANCANGAN MENARD (Menard's Design Rules)}

Menard mengeluarkan prinsip perancangan (design rules) dari hasil pengujian pressuremeter yang dapat digunakan secara langsung dalam perancangan geoteknik seperti perancangan pondasi dangkal, pondasi tiang, dinding penahan tanah, perkerasan dan persoalan interaksi tanah struktur. Dalam diagram dibawah ini digambarkan metode yang dipergunakan untuk mengaplikasikan hasil pengujian pressuremeter kedalam perancangan.

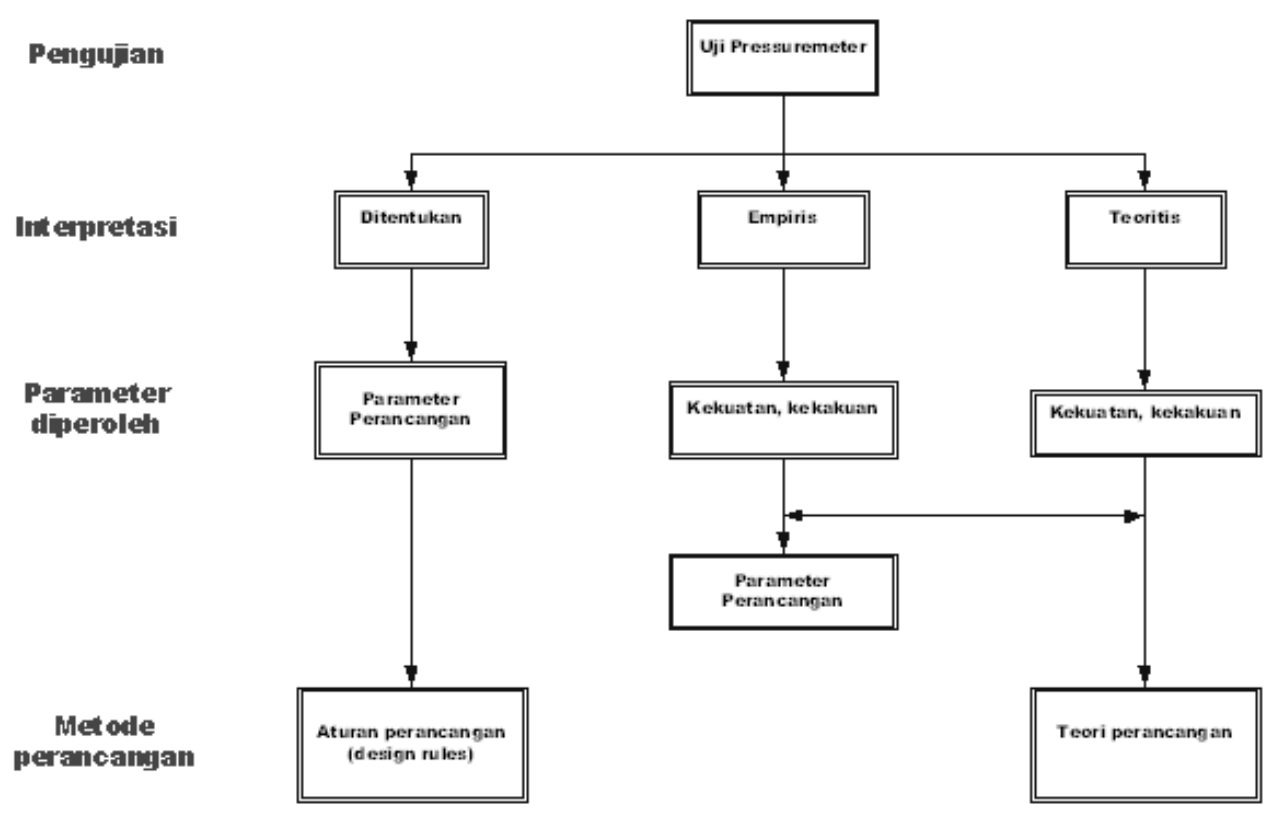

Gambar 3. Pressuremeter dalam perancangan geoteknik (Clarke, 1995). 
Dua parameter Menard pressuremeter yaitu $\mathrm{p}_{\mathrm{L}}$ dan $\mathrm{E}_{\mathrm{m}}$ dicoba dihubungkan dengan perilaku struktur dengan skala penuh dengan membuatkan korelasi empiris yang didukung dengan teori. Parameter pressuremeter adalah fungsi dari probe, metode instalasi, metode percobaan dan metode interpretasi. Dalam menggunakan prinsip perancangan Menard sangatlah penting untuk mendapatkan parameter pressuremeter sesuai dengan prosedur standar. Modulus Menard, $\mathrm{E}_{\mathrm{m}}$ dihitung dengan mempergunakan rumus :

$$
E_{m}=2 G_{m}(1+v)
$$

Tekanan batas (limit pressure), $\mathrm{p}_{\mathrm{L}}$ didefiniskan sebagai tekanan bila volume mencapai dua kali volume probe pada waktu awal $\left(\mathrm{DV} / \mathrm{V}_{0}=1\right)$. Berhubung derajat variasi dalam volume seringkali tidak tercapai, beberapa ekstrapolasi matematis diperlukan (berdasarkan model hiperbolik). Bila beberapa metode digunakan untuk menghitung $\mathrm{p}_{\mathrm{L}}$, dipilih harga rata-rata yang mewakili.

Rasio antara $E_{m}$ dan $p_{L}$ menurut Menard dapat digunakan untuk menunjukkan jenis tanah, hubungan dibawah ini banyak digunakan dalam tanah kohesif :

Tabel 2. Hubungan antara rasio $E_{m} / p_{L}$ dan jenis tanah (Schnaid, 2009).

\begin{tabular}{|l|l|}
\hline \multicolumn{1}{|c|}{$\mathrm{E}_{\mathrm{m}} / \mathrm{p}_{\mathrm{L}}$} & \multicolumn{1}{c|}{ Jenis tanah } \\
\hline $\mathrm{E}_{\mathrm{m}} / \mathrm{p}_{\mathrm{L}}<5$ & Lempung terganggu \\
\hline $5<\mathrm{E}_{\mathrm{m}} / \mathrm{p}_{\mathrm{L}}<8$ & Lempung terkonsolidasi kurang \\
\hline $8<\mathrm{E}_{\mathrm{m}} / \mathrm{p}_{\mathrm{L}}<12$ & Lempung terkonsolidasi normal \\
\hline $12<\mathrm{E}_{\mathrm{m}} / \mathrm{p}_{\mathrm{L}}<15$ & Lempung terkonsolidasi agak berlebih \\
\hline $\mathrm{E}_{\mathrm{m}} / \mathrm{p}_{\mathrm{L}}>15$ & Lempung terkonsolidasi sangat berlebih \\
\hline
\end{tabular}

Sebagai patokan umum, $\mathrm{E}_{\mathrm{m}} / \mathrm{p}_{\mathrm{L}}=10$ memberikan indikasi tanahnya adalah lempung terkonsolidasi normal. Untuk tanah butiran, rasio $\mathrm{E}_{\mathrm{m}} / \mathrm{p}_{\mathrm{L}}$ pada umumnya berkisar antara 7 sampai 12.

Penggunaan design rules dalam praktek rekayasa secara singkat garis besarnya diberikan dibawah ini. Design rules ini berdasarkan Peraturan Prancis untuk pondasi (Fascicle 62V - M.E.L.T, 1983) dan sesuai dengan EuroCode 7. Prosedur langkah demi langkah merancang dengan hasil pengujian pressuremeter secara detil dapat dilihat pada Baguelin et al.(1985) dan Briaud (1992).

\subsection{Daya dukung pondasi dangkal}

Dalam pendekatan ini, hubungan antara daya dukung $\mathrm{q}_{\mathrm{b}}$ dari suatu pondasi dan tekanan batas (limit pressure) $\mathrm{p}_{\mathrm{L}}$ yang diperoleh dari pengujian pressuremeter Menard dihubungkan dengan rasio rongga berbentuk bola dan berbentuk silinder. Dari latar 
belakang konsep seperti ini dan berdasarkan percobaan beban skala penuh, faktor daya dukung $\mathrm{k}_{\mathrm{p}}$ didefinisikan sebagai berikut:

$$
k_{p}=\frac{q_{b}-\sigma_{V}}{p_{L}-p_{0}}
$$

dimana $p_{L}-p_{0}$ adalah sama dengan net limit pressure dalam daerah pengaruh pondasi, $\sigma_{V}$ adalah tegangan vertikal total pada dasar pondasi dan $p_{0}$ adalah tekanan horizontal total yang diperoleh dari pengujian pressuremeter. Nilai $p_{L}-p_{0}$ didapat dari :

$$
\left(p_{L}-p_{0}\right)_{e}=\sqrt[n]{\left(p_{L}-p_{0}\right)_{1}\left(p_{L}-p_{0}\right)_{2} \ldots \ldots \ldots\left(p_{L}-p_{0}\right)_{n}}
$$

dimana $\mathrm{n}$ adalah jumlah pengujian pressuremeter dalam kedalaman 1.5 B dari dasar pondasi dan $\mathrm{B}$ adalah lebar dari pondasi. Pendekatan ini menggunakan kedalaman pondasi ekivalen, yang dihitung dari :

$$
D_{e}=\frac{1}{\left(p_{L}-p_{0}\right)_{e}} \int_{0}^{D}\left(p_{L}-p_{0}\right)(z) d z
$$

dimana $z$ adalah tebal lapisan dengan net limit pressure. Definisi ini memungkinkan lapisan yang lebih kuat atau lebih lemah didalam kedalaman pengaruh pondasi yang diperhitungkan. Dengan menggunakan data masukan ini, fak tor daya dukung $\mathrm{k}_{\mathrm{p}}$ dapat dihitung dari Tabel 3 atau sebagai alternatif dari Gambar 4 untuk pondasi bujur sangkar

\begin{tabular}{|c|c|c|c|c|}
\hline $\begin{array}{l}\text { Soil } \\
\text { category }\end{array}$ & Class & $\begin{array}{l}\text { Expression } \\
\text { for } k_{p}\end{array}$ & $\begin{array}{l}k_{p} \text { square } \\
\text { and circular } \\
\text { footings }\end{array}$ & $\begin{array}{l}k_{p} \text { strip } \\
\text { footing }\end{array}$ \\
\hline $\begin{array}{l}\text { Clay and silt } \\
\text { Chalk }\end{array}$ & A & $0.8\left[1+0.25\left(0.6+0.4 \frac{B}{L}\right) \frac{D_{\mathrm{e}}}{B}\right]$ & 1.30 & 1.10 \\
\hline Clay and silt & B & $0.8\left[1+0.35\left(0.6+0.4 \frac{B}{L}\right) \frac{D_{\mathrm{e}}}{B}\right]$ & 1.50 & 1.22 \\
\hline Clay & $\mathrm{C}$ & $0.8\left[1+0.50\left(0.6+0.4 \frac{B}{L}\right) \frac{D_{\mathrm{c}}}{B}\right]$ & 1.80 & 1.40 \\
\hline Sand & A & {$\left[1+0.35\left(0.6+0.4 \frac{B}{L}\right) \frac{D_{\mathrm{e}}}{B}\right]$} & 1.88 & 1.53 \\
\hline Sand and gravels & B & {$\left[1+0.50\left(0.6+0.4 \frac{B}{L}\right) \frac{D_{\mathrm{c}}}{B}\right]$} & 2.25 & 1.75 \\
\hline Sand and gravels & $\mathrm{C}$ & {$\left[1+0.80\left(0.6+0.4 \frac{B}{L}\right) \frac{D_{\mathrm{e}}}{B}\right]$} & 3.00 & 2.20 \\
\hline Chalk & B-C & $1.3\left[1+0.27\left(0.6+0.4 \frac{B}{L}\right) \frac{D_{\mathrm{c}}}{B}\right]$ & 2.18 & 1.83 \\
\hline $\begin{array}{l}\text { Marl and weathered } \\
\text { rock }\end{array}$ & - & {$\left[1+0.27\left(0.6+0.4 \frac{B}{L}\right) \frac{D_{\mathrm{e}}}{B}\right]$} & 1.68 & 1.41 \\
\hline
\end{tabular}
dan lingkaran dan dari Gambar 5 untuk pondasi jalur.

Tabel 3. Faktor daya dukung $k_{p}$ untuk pondasi dangkal (Frank, 1999). 


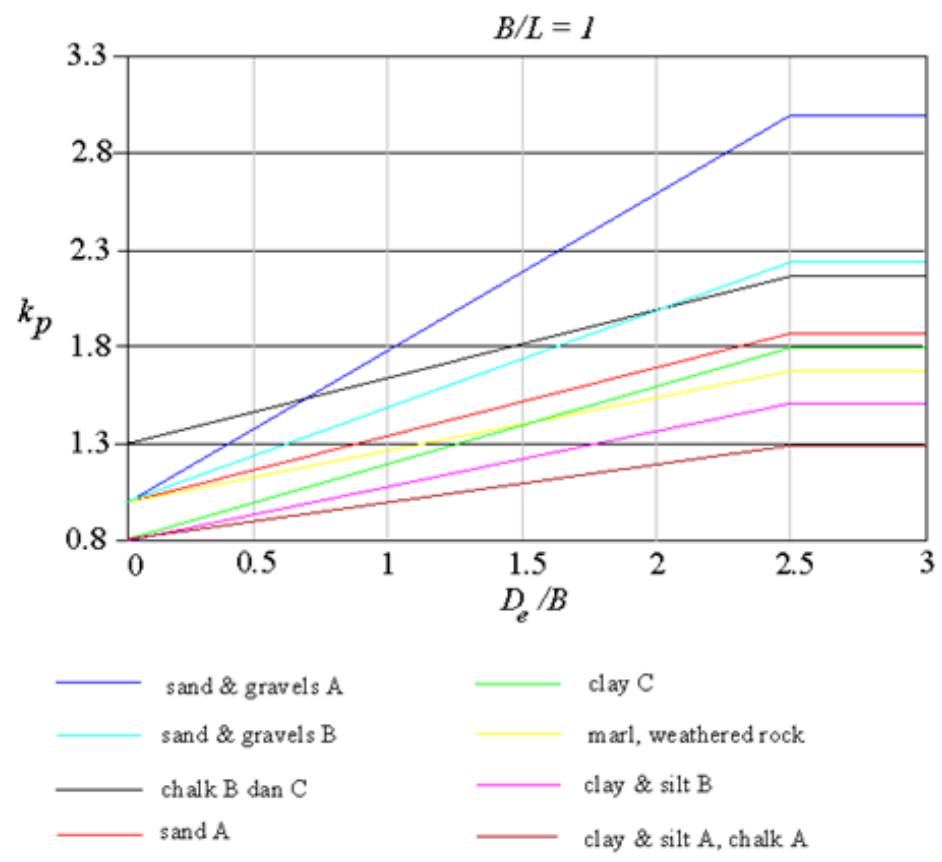

\section{Gambar 4. Faktor daya dukung $k_{p}$ untuk pondasi bujur sangkar dan lingkaran (Frank, 1999).}

Suatu faktor reduksi $i_{\delta, \beta}$ akan dipergunakan untuk persamaan $k_{p}$ persamaan (3) bila dipergunakan untuk menghitung daya dukung untuk pondasi yang dibebani oleh beban yang miring atau untuk pondasi yang berdekatan dengan galian atau lereng :

$$
i_{\delta, \beta}=\left(1-\frac{A}{90}\right)^{2}(1-\lambda)+\left(1-\frac{A}{20}\right) \lambda
$$

dimana A adalah kemiringan dari beban $\delta$ kemiringan dari galian $\beta$. Nilai $\lambda$ didefinisikan sebagai :

$$
\begin{aligned}
& \lambda=\lambda_{D} \lambda_{M} \\
& \lambda_{D}=(1-D / B) \ldots \ldots \ldots \ldots \ldots \ldots \ldots . . .0<D / B<1
\end{aligned}
$$

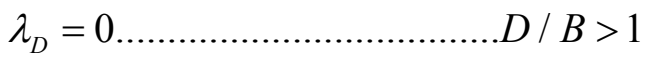

$$
\begin{aligned}
& \lambda_{M}=(1-M) \ldots \ldots \ldots \ldots \ldots \ldots \ldots \ldots . . . .0<M<1
\end{aligned}
$$

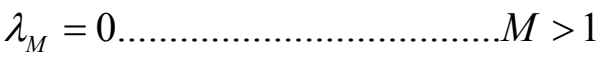

dimana $\mathrm{D}$ adalah kedalaman pondasi dan $\mathrm{M}$ dinyatakan sebagai :

$$
M=\frac{\left(p_{L}-p_{0}\right)_{Z=D}}{\left(p_{L}-p_{0}\right)_{Z=D+B}}
$$




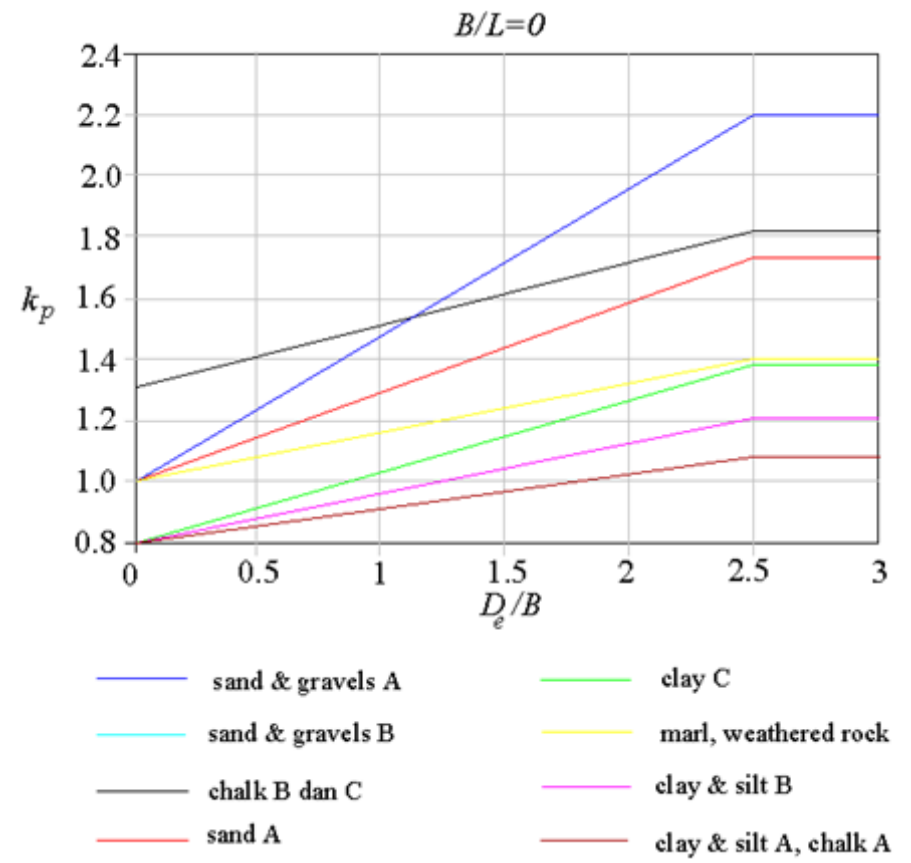

Gambar 5. Faktor daya dukung $k_{p}$ untuk pondasi jalur (Frank, 1999).

Bila beban miring kearah lereng, faktor disesuaikan sehingga $A=\left(\delta+\beta^{\prime}\right)$. Koefisien koreksi ini diperlihatkan dalam Gambar 6. Faktor koreksi ini dinyatakan dalam Gambar 6 untuk empat kondisi yang berbeda: (a) beban miring pada permukaan yang horizontal, (b) beban vertikal dekat sebuah lereng, tanpa galian, (c) beban vertikal, dekat sebuah lereng dengan pondasi tertanam dan (d) tegangan longsor untuk beban miring, dekat sebuah lereng (Frank, 1999).

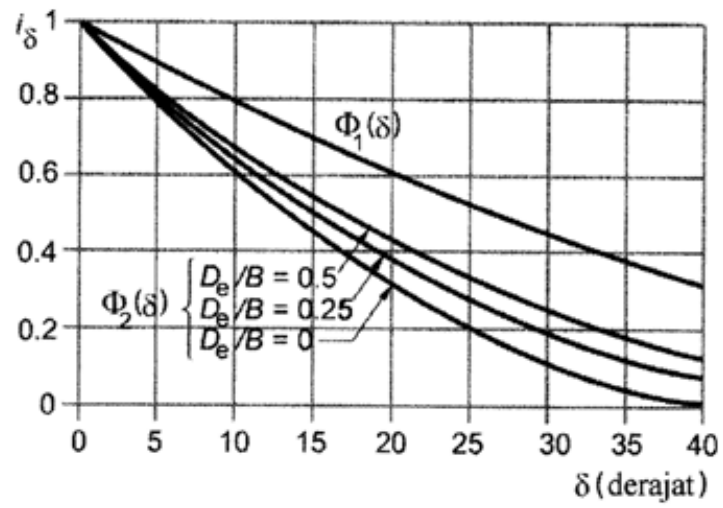

- Cohesive soils (clays, silts, marls), chalks,calcareous marls and weathered rocks:

$$
i_{\delta}=\Phi_{1}(\delta)
$$

- Granular soils (sands and gravels)

$$
i_{\delta}=\Phi_{2}(\delta)
$$

(a) pembebanan miring untuk tanah yang horizontal.

Gambar 6. Pengurangan daya dukung $k_{p}$ untuk pembebanan yang miring atau dekat dengan galian lereng untuk pembebanan tegak (Frank, 1999). 


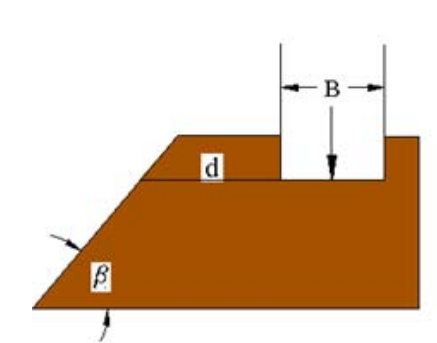

$i_{\beta}=\Psi(\beta, d / B)$

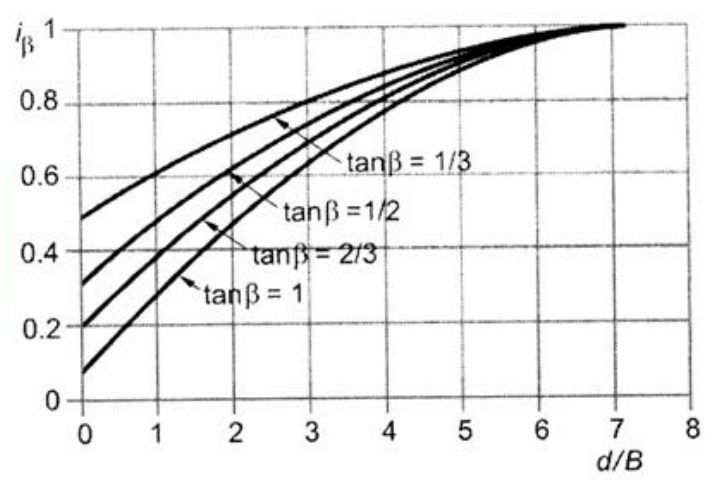

(b) beban vertikal dekat sebuah lereng.

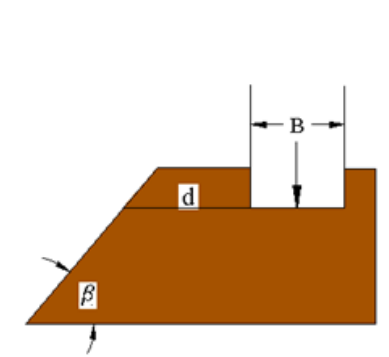

$$
\begin{aligned}
& i_{\beta}=\Psi(\beta, d / B) \\
& \beta^{\prime}=45\left(1-i_{\beta}^{1 / 2}\right) \\
& i_{\delta \beta}=\Phi_{2}\left(\beta^{\prime}\right)
\end{aligned}
$$

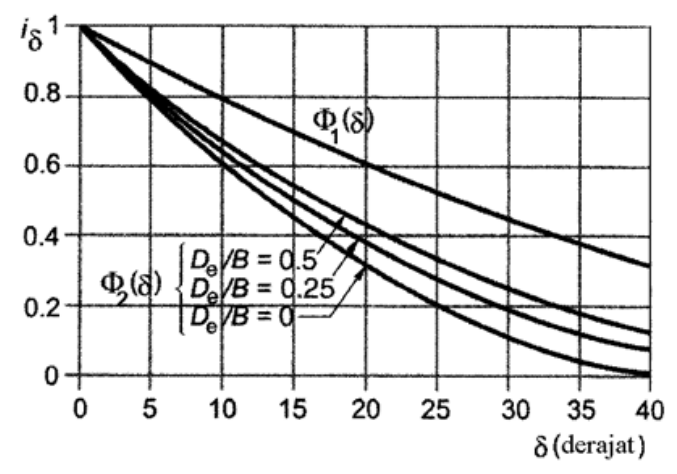

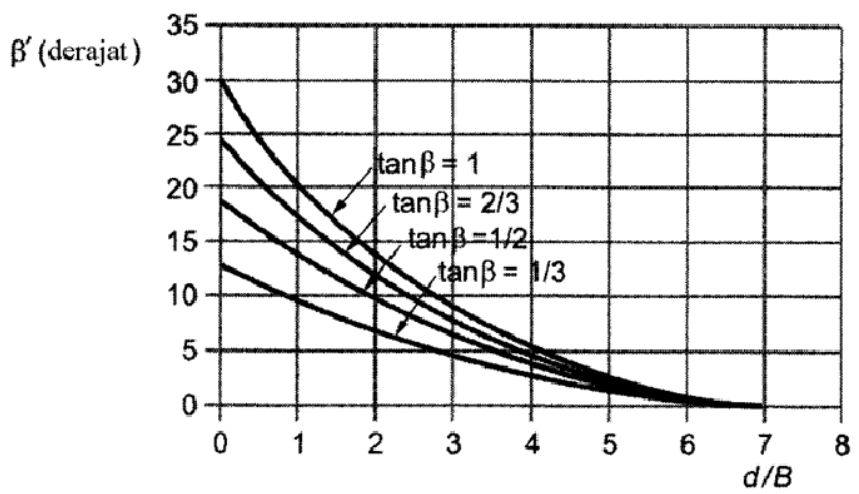

(c) beban vertikal dekat sebuah lereng, pondasi tertanam pada suatu kedalaman.

Gambar 6. Pengurangan daya dukung $k_{p}$ untuk pembebanan yang miring atau dekat dengan galian lereng untuk pembebanan tegak (Frank, 1999)

$$
\text { (lanjutan). }
$$


1

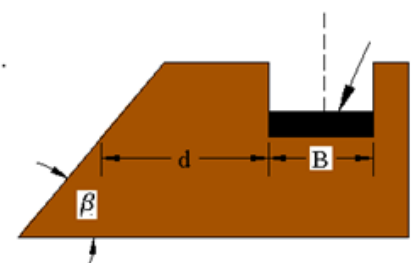

1.kemiringan kearah luar dari lereng $i_{\delta \beta}=\Phi_{2}(\delta+\beta)$

2.kemiringan kearah dalam dari lereng ${ }^{i} \delta \beta=\inf \left\{\Phi_{1}(\delta)\right.$ or $\left.\Phi_{2}(\delta) ; \Phi_{2}\left(\left|\beta^{\prime}-\delta\right|\right)\right\}$

(d) tegangan longsor untuk beban miring dekat sebuah lereng

\section{Gambar 6. Pengurangan daya dukung $k_{p}$ untuk pembebanan yang miring atau dekat dengan galian lereng untuk pembebanan tegak (Frank, 1999) \\ (lanjutan).}

\subsection{Penurunan pondasi dangkal}

Sebagaimana disarankan oleh Menard dan Rousseau (1962), penurunan dari suatu pondasi adalah fungsi dari kekakuan isotropis $E_{c}$ dan selisih kekakuan $E_{d}$. Kedua besaran itu dapat diturunkan dari data pressuremeter dari mana penurunan untuk 10 tahun $\rho$ dari suatu pondasi yang kaku dapat diturunkan, dengan kedalaman pondasi lebih besar dari lebar pondasi B:

$$
\rho=\frac{2\left(q-\sigma_{v 0}\right) B_{0}}{9 E_{d}}\left(\lambda_{d} \frac{B}{B_{0}}\right)^{\alpha}+\frac{\alpha \lambda_{c}\left(q-\sigma_{v 0}\right) B}{9 E_{c}}
$$

dimana $\mathrm{B}_{0}$ adalah lebar acuan yang diambil $=0.60$ meter, $\lambda_{c}$ dan $\lambda_{d}$ adalah faktor bentuk yang terdapat dalam Tabel 4, $\alpha$ adalah faktor rheologis yang dapat dilihat pada Tabel 5 dan q adalah tekanan dukung pondasi.

Suatu prosedur yang detil harus diikuti untuk menghitung penurunan dari persamaan (8). Tanah dibawah pondasi perlu dibagi menjadi 16 bagian dengan tebal per lapis $\mathrm{B} / 2$, sebagaimana diperlihatkan dalam gambar 7. Berhubung kekakuan isotropis yang maksimum berada langsung dibawah pondasi, $\mathrm{E}_{\mathrm{c}}$ diambil sama dengan $\mathrm{E}_{1}$, dihitung sebagai :

$$
\frac{4}{E_{d}}=\frac{1}{E_{1}}+\frac{1}{0.85 E_{2}}+\frac{1}{E_{3,5}}+\frac{1}{E_{6,8}}+\frac{1}{2.5 E_{9,16}}
$$


dengan suatu harmonik rata-rata setiap lapisan $\left(E_{3,5}, E_{6,8}, E_{9,16}\right)$ dalam persamaan (9).

Tabel 4. Koefisien bentuk untuk pondasi dangkal (Frank, 1999).

\begin{tabular}{|c|c|c|c|c|c|c|}
\hline L/2B & Lingkaran & $\begin{array}{c}\text { Bujur } \\
\text { Sangkar }\end{array}$ & $\mathbf{2}$ & $\mathbf{3}$ & $\mathbf{5}$ & $\mathbf{2 0}$ \\
\hline$\lambda \mathrm{c}$ & 1 & 1.12 & 1.53 & 1.78 & 2.14 & 2.65 \\
\hline$\lambda_{\mathrm{d}}$ & 1 & 1.10 & 1.20 & 1.30 & 1.40 & 1.50 \\
\hline
\end{tabular}

Tabel 5. Koefisien auntuk pondasi dangkal (Frank, 1999).

\begin{tabular}{|c|c|c|c|}
\hline Jenis Tanah & Keterangan & $\boldsymbol{E}_{\boldsymbol{m}} \boldsymbol{p}_{\boldsymbol{L}}$ & $\boldsymbol{\alpha}$ \\
\hline Gambut & Konsolidasi normal & & 1 \\
\hline Lempung & Konsolidasi berlebih & $>16$ & 1 \\
\hline & Konsolidasi normal & $9-16$ & $2 / 3$ \\
\hline & Terganggu & $7-9$ & $1 / 2$ \\
\hline Lanau & Konsolidasi berlebih & $>14$ & $2 / 3$ \\
\hline & Konsolidasi normal & $8-14$ & $1 / 2$ \\
\hline Lanau & Terganggu & $5-8$ & $1 / 2$ \\
\hline Pasir & Konsolidasi berlebih & $>12$ & $1 / 2$ \\
\hline & Konsolidasi normal & $7-12$ & $1 / 3$ \\
\hline & Terganggu & $5-7$ & $1 / 3$ \\
\hline Pasir \& kerikil & Konsolidasi berlebih & $>10$ & $1 / 3$ \\
\hline & Konsolidasi normal & $6-10$ & $1 / 4$ \\
\hline Batuan & Sedikit hancur & & $2 / 3$ \\
\hline & Tidak berubah & & $1 / 2$ \\
\hline & Sangat hancur & & $1 / 3$ \\
\hline & Sangat lapuk & & \\
\hline
\end{tabular}

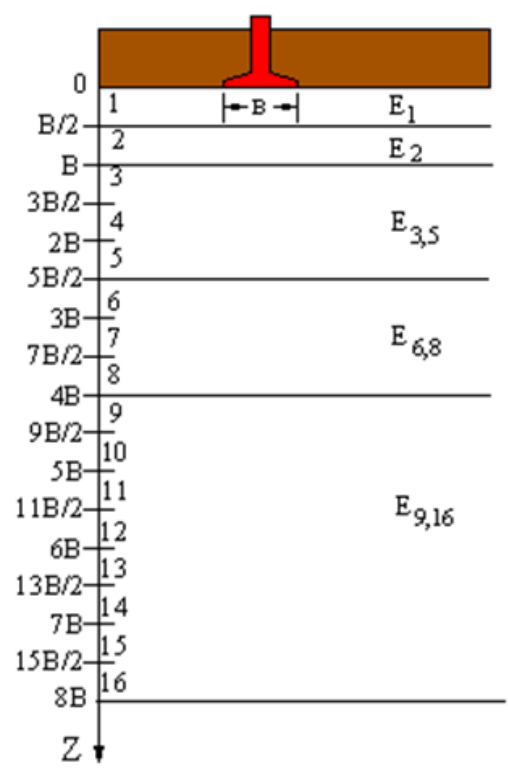

Gambar 7. Diskritisasi tanah kedalam lapisan untuk analisa penurunan

(Frank 1999). 


\subsection{Daya dukung pondasi tiang akibat beban vertikal}

Metode untuk mendapatkan daya dukung tiang pada garis besarnya sama dengan untuk pondasi dangkal dan diusulkan oleh Menard (1963). Daya dukung ujung tiang $\mathrm{Q}_{\mathrm{b}}$ dinyatakan oleh rumus :

$$
\frac{Q_{b}}{A_{b}}=k_{p}\left(p_{L}-P_{0}\right)_{e}+\sigma_{v}
$$

dimana $\mathrm{A}$ adalah luas dasar dari tiang, $\mathrm{P}_{0}$ tegangan total horizontal at rest dan $\mathrm{k}_{\mathrm{p}}$ faktor daya dukung. Prosedur untuk menentukan tegangan batas net digambarkan dalam Gambar 8, dimana $\left(\mathrm{p}_{\mathrm{L}}-\mathrm{P}_{0}\right)_{\mathrm{e}}$ dihitung dari :

$$
\left(p_{L}-P_{0}\right)_{e}=\frac{1}{3 a+b} \int_{D-b}^{D+3 a}\left(p_{L}-P_{0}\right)(z) d z
$$

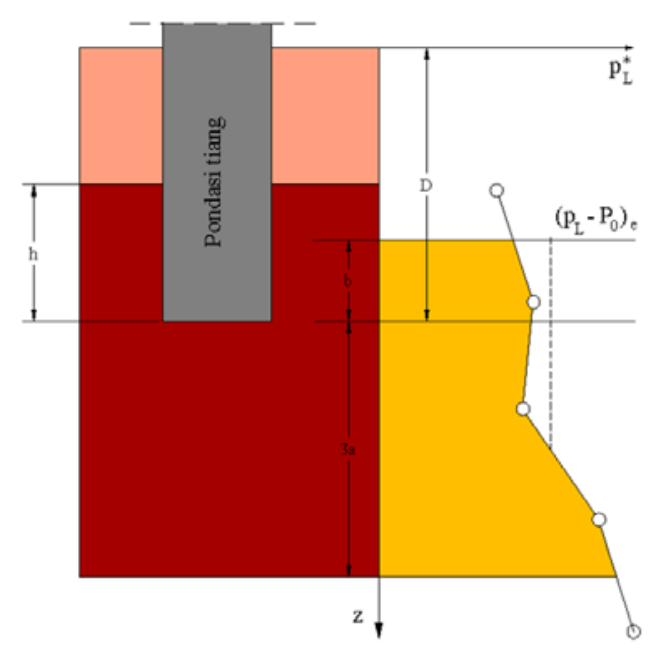

Gambar 8. Perkiraan tekanan batas ekivalen net untuk perhitungan daya dukung tiang (Frank, 1999).

Nilai a dan $\mathrm{b}$ dianggap :

- $\mathrm{a}=\mathrm{B} / 2 \quad$ bila $\mathrm{B}>1 \mathrm{~m}$

- $\mathrm{a}=0.5 \mathrm{~m} \quad$ bila $\mathrm{B}<1 \mathrm{~m}$

- $\mathrm{b}=$ minimum dari $\mathrm{a}$ dan $\mathrm{b}$

dimana $\mathrm{h}$ adalah masuknya tiang kedalam lapisan pendukung. $\mathrm{B}$ adalah diameter ekivalen dari tiang dianggap $\mathrm{B}=(4 \mathrm{~A} / \mathrm{P}), \mathrm{A}$ dan $\mathrm{P}$ adalah luas dan keliling dari potongan tiang.

Nilai faktor daya dukung dapat dilihat pada Tabel 6 untuk tiang pancang atau tiang bor dengan anggapan kedalaman pembenaman $\mathrm{D}_{\mathrm{e}}>5 \mathrm{~B}$. Kedalaman pembenaman ekivalen sama dengan seperti dalam persamaan (4). 
Nilai $\mathrm{k}_{\mathrm{p}}$ berkurang menjadi $\mathrm{k}_{\mathrm{e}}$ bila $\mathrm{D}_{\mathrm{e}}<5 \mathrm{~B}$ :

$$
k_{e}=0.8+\left(\frac{k-0.8}{25}\right) \frac{D_{e}}{B}\left(\frac{10-D_{e}}{B}\right)
$$

Kapasitas lekatan pada tiang Q, dapat ditentukan dari :

$$
Q_{s}=P \int_{0}^{h} q_{s} d z
$$

dimana $\mathrm{q}_{\mathrm{s}}$ adalah unit gesekan yang diperoleh dari Tabel 7 bersamaan dengan Gambar 9 . Dalam pendekatan ini, gesekan pada tiang tidak tergantung hanya pada tekanan batas pressuremeter, tapi tergantung dari jenis tanah, jenis tiang dan kondisi pelaksanaan tiang.

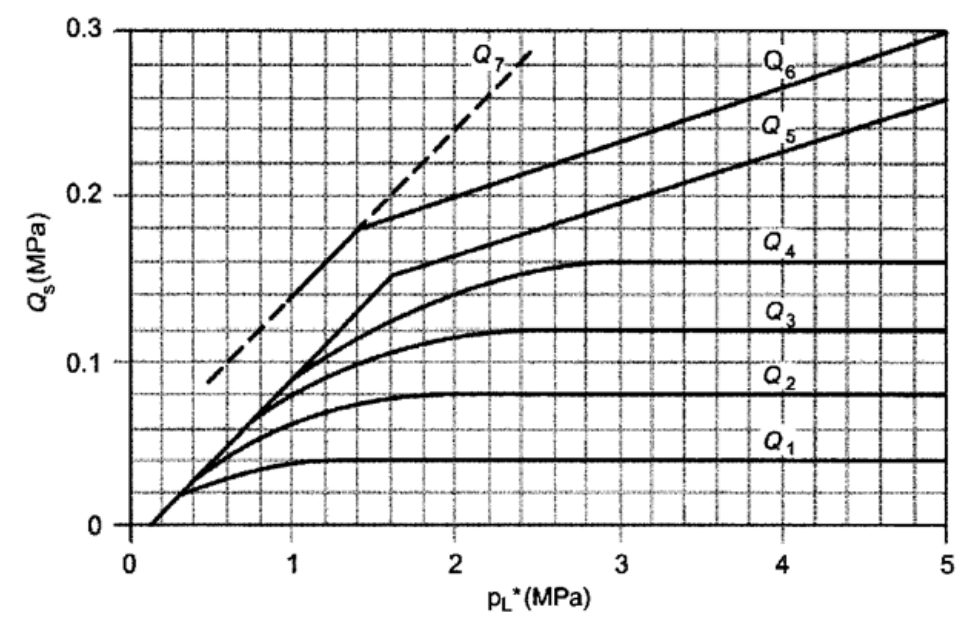

Gambar 9. Unit lekatan selimut untuk tiang yang dibebani aksial (Bustamante dan Frank, 1999).

Tabel 6. Faktor daya dukung $k_{\mathrm{p}}$ untuk tiang yang dibebani aksial

\begin{tabular}{|c|c|c|c|c|c|c|}
\hline \multirow[t]{2}{*}{ Soil type } & & & \multicolumn{2}{|c|}{$\begin{array}{l}\text { Range of } \\
\text { measurements }\end{array}$} & \multirow[t]{2}{*}{$\begin{array}{l}\text { Non-displacement } \\
\text { piles } k_{p}\end{array}$} & \multirow[t]{2}{*}{$\begin{array}{l}\text { Displacement } \\
\text { piles } k_{p}\end{array}$} \\
\hline & & & $\begin{array}{l}P_{L M} \\
\left(M N / m^{2}\right)\end{array}$ & $\begin{array}{l}q_{c} \\
\left(\mathrm{MN} / \mathrm{m}^{2}\right)\end{array}$ & & \\
\hline Clay & A & soft & $<0.7$ & $<3$ & 1.1 & 1.4 \\
\hline \multirow[t]{2}{*}{ Silt } & B & stiff & $1.2-2$ & $3-6$ & 1.2 & 1.5 \\
\hline & $\mathrm{C}$ & hard (clay) & $>2.5$ & $>6$ & 1.3 & 1.6 \\
\hline Sand & A & loose & $<0.5$ & $<S$ & 1 & 4.2 \\
\hline \multirow{2}{*}{ Gravel } & B & medium & $1-2$ & $8-15$ & 1.1 & 3.7 \\
\hline & $\mathrm{C}$ & dense & $>2.5$ & $>20$ & 1.2 & 3.2 \\
\hline \multirow[t]{3}{*}{ Chalk } & A & soft & $<0.7$ & $<5$ & 1.1 & 1.6 \\
\hline & B & weathered & $1-2.5$ & $>5$ & 1.4 & 2.2 \\
\hline & $\mathrm{C}$ & dense & $>3$ & - & 1.8 & 2.6 \\
\hline Marl & $\mathrm{A}$ & soft & $1.5-4$ & - & 1.8 & 2.6 \\
\hline $\begin{array}{l}\text { Calcareous } \\
\text { marl }\end{array}$ & B & dense & $>4.5$ & - & 1.8 & 2.6 \\
\hline \multirow[t]{2}{*}{ Rock } & A & weathered* & $2.5-4$ & - & $1.1-1.8$ & $1.8-3.2$ \\
\hline & B & fragmented & 4.5 & - & - & - \\
\hline
\end{tabular}
(Bustamante\& Frank (1999) 


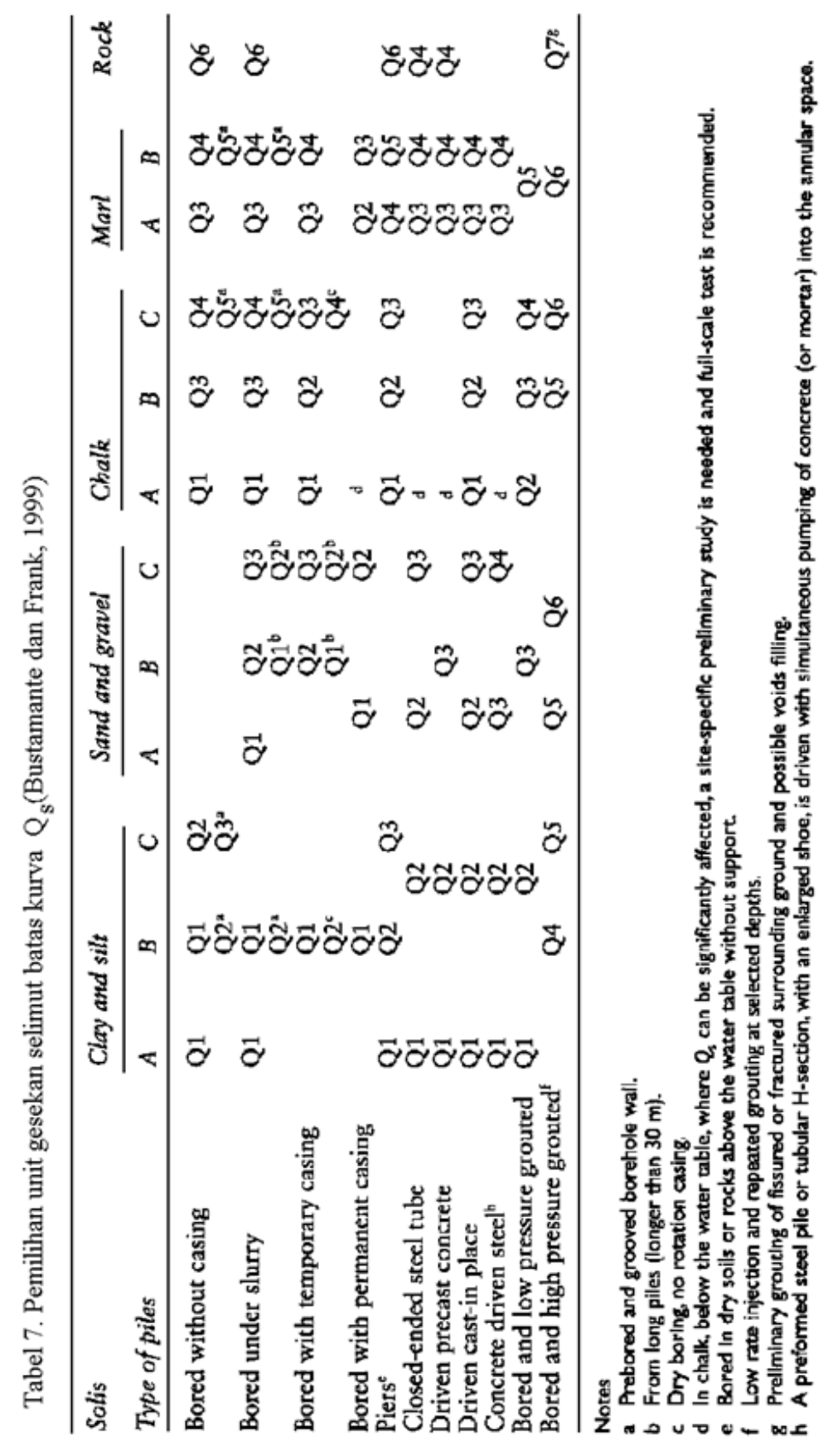

\subsection{Penurunan tiang tunggal}

Penurunan tiang tunggal pada setengah beban batas diambil sebagai persentasi dari diameter tiang, ditambah jumlah perpendekan elastis dari bagian tiang yang bebas (bila ada). Persentasinya adalah sebagai berikut (Frank, 1999) :

$\mathrm{w}=0.6 \% \mathrm{~B}$ untuk tiang bor

$\mathrm{w}=0.9 \% \mathrm{~B}$ untuk tiang pancang 
dimana $\mathrm{w}$ adalah penurunan tiang dan $\mathrm{B}$ adalah diameter tiang.

Kurva beban - penurunan yang lengkap dapat diturunkan dari data uji pressuremeter bila kurva unit tahanan ujung - peralihan ( $\mathrm{f}-\mathrm{w}$ ) dan kurva unit gesekan selimut - peralihan $(\mathrm{q}-\mathrm{w})$ diperoleh. Tiga buah prosedur dapat dipergunakan untuk menurunkan kurva $(\mathrm{f}-\mathrm{w})$ dan $(\mathrm{q}-\mathrm{w})$ sebagaimana dilukiskan dalam Gambar 10 (Gambin, 1963; Baguelin, 1982; Frank \& Zhao, 1982; Frank, 1999).
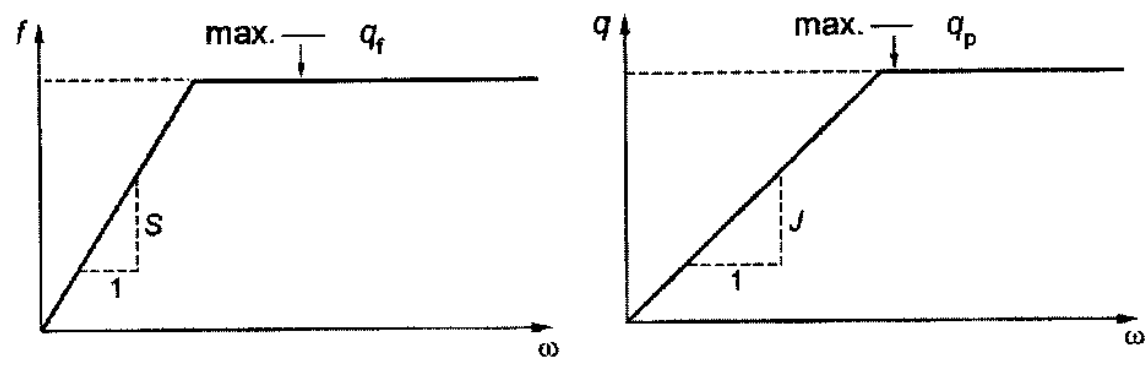

(a)
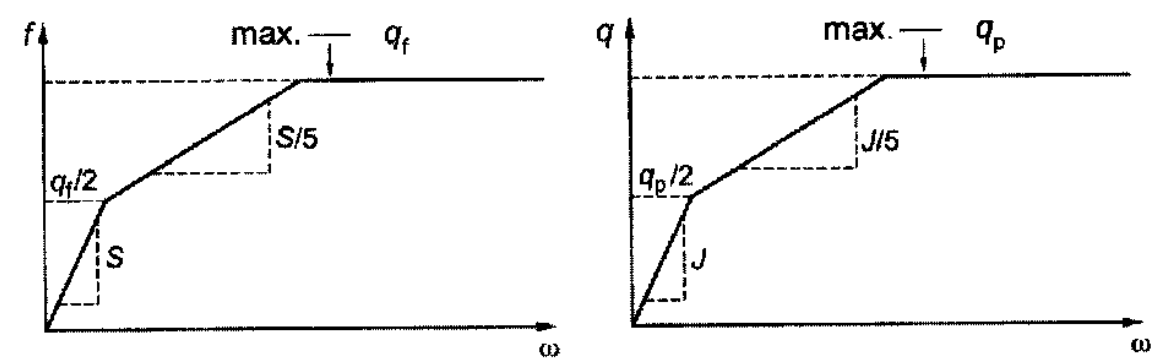

(b)

(a) Gambin (1963); (b) Frank dan Zhao (1982).

Gambar 10. Model elastis-plastis untuk menentukan penurunan pondasi tiang yang dibebani aksial menggunakan metode transfer beban:

Perbedaan yang signifikan antara kedua pendekatan ini berkenaan dengan rekomendasi untuk kemiringan dari bagian yang elastis dari kurva. Metode yang disarankan oleh Gambin (1963) menganggap model elastis-plastis sederhana, sedangkan metode yang disarankan oleh Frank dan Zhou (1982) menganggap dua garis linier (bilinear) model elastis-plastis untuk mendekati data hasil eksperimental dengan skala penuh dari pondasi tiang bor.

Mengambil contoh dari metode Frank dan Zhou, untuk tanah butir halus, kemiringan $\mathrm{J}$, digunakan untuk menentukan penurunan dasar dan kemiringan $\mathrm{S}$ untuk menentukan penurunan selimut sebagai berikut :

$$
J=\frac{q}{w_{b}}=11.0 \frac{E_{m}}{B} \text { dan } S=\frac{f}{w_{s}}=2.0 \frac{E_{m}}{B}
$$


Untuk tanah berbutir, nilai $\mathrm{J}$ dan $\mathrm{S}$ dinyatakan sebagai :

$$
J=\frac{q}{w_{b}}=\frac{4 E_{m}}{\pi\left(1-v^{2}\right) B} \text { dan } S=\frac{f}{w_{s}}=\frac{E_{m}}{(1+v)\left(1+\ln \frac{L}{B}\right) B}
$$

Sebagai alternatif, Baguelin et al. (1978) menyarankan persamaan berikut ini untuk pondasi tiang pancang :

$$
J=\frac{q}{w_{b}}=4.8 \frac{E_{m}}{B} \text { dan } S=\frac{f}{w_{s}}=0.8 \frac{E_{m}}{B}
$$

Fase awal dari kurva transfer beban dapat diturunkan dari persamaan (14) - persamaan (16). Diskritisasi sebuah tiang kedalam elemen terpisah memungkinkan integrasi numerik dari gaya dan perpindahan sepanjang selimut tiang. Perhitungan ini biasanya menggunakan program komputer, dimana setiap elemen berkaitan dengan kurva ( $\mathrm{q}-\mathrm{w})$ dan (f-w) nya masing-masing.

\subsection{Tiang yang yang dibebani secara horizontal}

Alat presuremeter adalah model yang sempurna untuk sebuah prototip pondasi tiang yang dibebani secara horizontal, dalam segi bentuk dan arah pembebanannya. Kesamaan ini sudah dikenali oleh Menard et al. (1975) dan Gambin (1979), yang menghasilkan prosedur yang direncanakan untuk pembuatan 'kurva p-y " dari data pressuremeter (Matlock, 1970; Reese, 1977).

Kurva p-y menghubungkan reaksi tanah dengan defleksi tiang yang menyatakan perilaku non linier dari tanah sepanjang tiang. Kurva p-y dari hasil uji pressuremeter Menard dinyatakan oleh kurva-kurva pada Gambar 11, dimana beban lateral $\mathrm{P}$ digambarkan terhadap pergeseran horizontal y (Frank, 1999).

Modulus reaksi $\mathrm{E}_{\mathrm{s}}$, didefinisikan dalam gambar 11 oleh persamaan :

$$
E_{s}=\frac{P}{y}
$$

$\mathrm{E}_{\mathrm{s}}$ diketahui tidak linier. Dalam tiang dimana beban horizontal dominan terhadap keadaan lainnya, respon non linier ini dinyatakan dalam model elastis-plastis bilinier dengan kemiringan bagian linier yang pertama dari kurva adalah $\mathrm{E}_{\mathrm{s}}$ dan kemiringan yang kedua adalah separuh dari yang pertama $\left(=\mathrm{E}_{\mathrm{s}} / 2\right)$.

Sebuah rekomendasi telah dibuat bahwa tahanan batas dipermukaan dikurangi menjadi $1 / 2 \mathrm{p}_{\mathrm{L}}$. Pengaruh pengurangan ini digambarkan dalam Gambar 12 dan 
dipergunakan untuk tanah diatas kedalaman kritis, yang diambil $=2 \mathrm{~B}$ untuk lempung dan $=4 \mathrm{~B}$ untuk pasir.

Modulus reaksi dari Menard (1975) dihitung dengan persamaan :

$$
\begin{array}{ll}
E_{s}=E_{m} \frac{18}{4\left(2.65 \frac{B}{B_{0}}\right)^{\alpha} \frac{B}{B_{0}}+3 \alpha} & \text { untuk B }>0.60 \mathrm{~m} \\
E_{s}=E_{m} \frac{18}{4(2.65)^{\alpha}+3 \alpha} & \text { untuk B } \leq 0.60 \mathrm{~m}
\end{array}
$$

dimana $\mathrm{B}$ adalah diameter tiang, $\mathrm{B}_{0}$ adalah diameter acuan $(=0.60 \mathrm{~m})$ dan a adalah koefisien yang ada dalam Tabel 5. Kurva $p-y$ yang mewakili tiap lapisan tanah dapat diturunkan dari persamaan diatas, dari mana distribusi defleksi tiang, momen lentur dan gaya geser dapat ditentukan secara numerik.

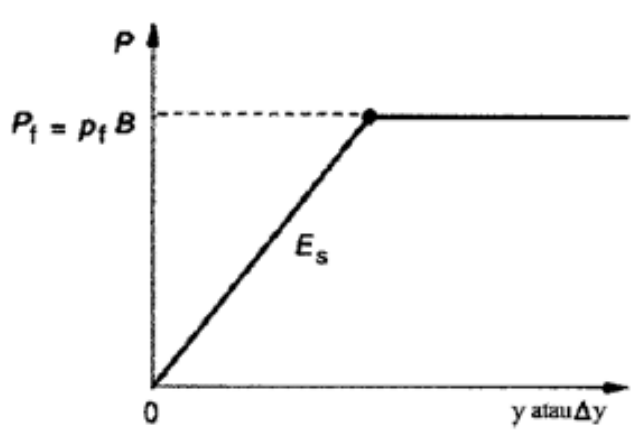

(a)

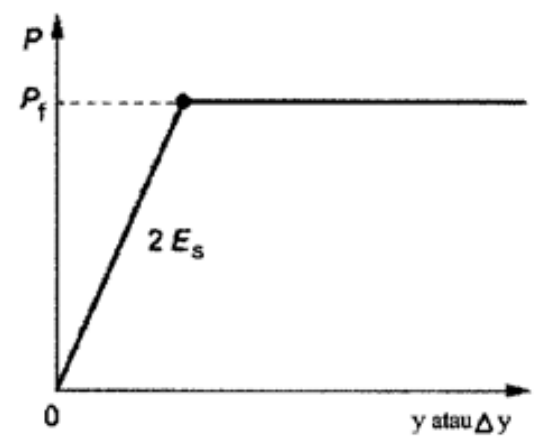

(c)

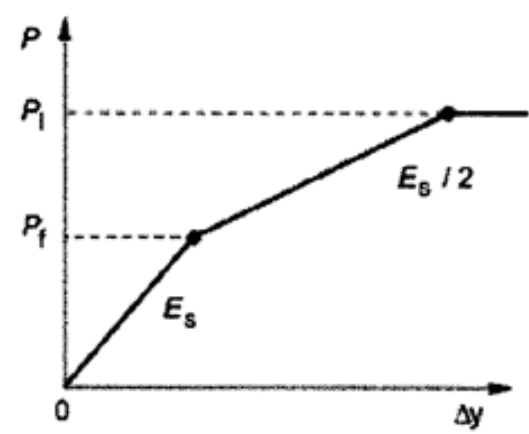

(b)

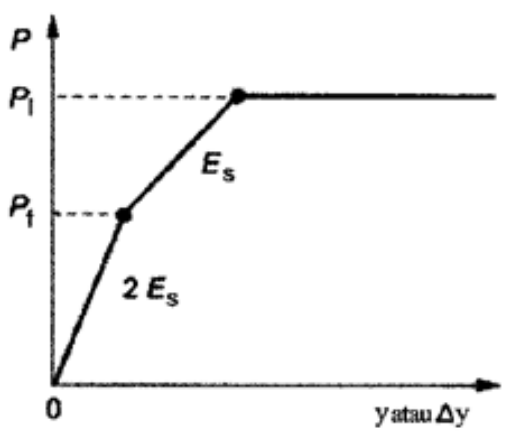

(d)

(a) beban tetap pada kepala tiang;

(b) dorongan lateral sepanjang selimut tiang;

(c) beban jangka pendek pada kepala tiang;

(d) beban jangka pendek tidak tetap pada kepala tiang

Gambar 11. Kurva reaksi untuk pondasi tiang tunggal yang dibebani dengan beban horizontal (Frank, 1999). 


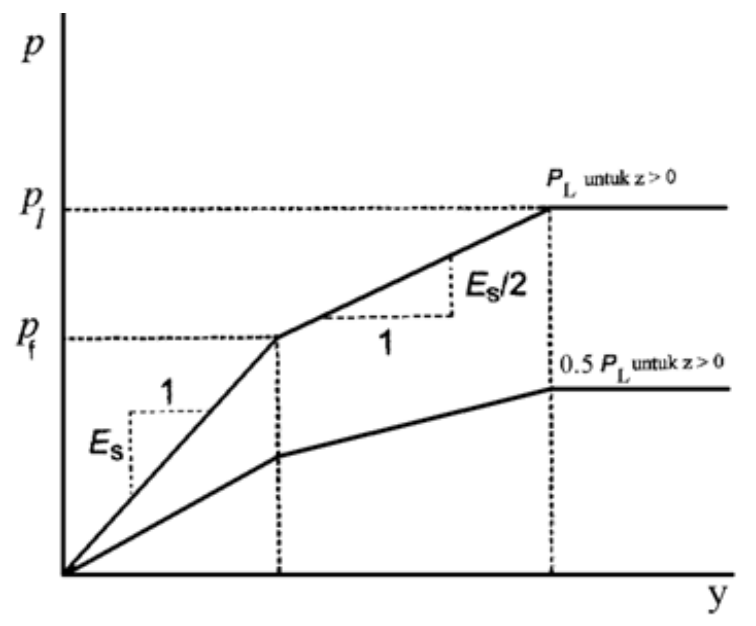

Gambar 12. Kurva reaksi didalam dan dibawah kedalaman kritis

(Baguelin et al., 1978).

\section{PARAMETER TANAH YANG DIPEROLEH DARI UJI PRESSUREMETER} YANG TIDAK DIPERGUNAKAN SECARA LANGSUNG

Dibagian atas telah dibahas mengenai penggunaan hasil uji pressuremeter secara langsung dengan menggunakan Menard's rule. Dalam praktek, parameter tanah yang dihasilkan dari hasil uji pressuremeter dapat digunakan juga didalam analisa persoalan geoteknik dengan cara tidak langsung (tidak menggunakan Menard's rule).

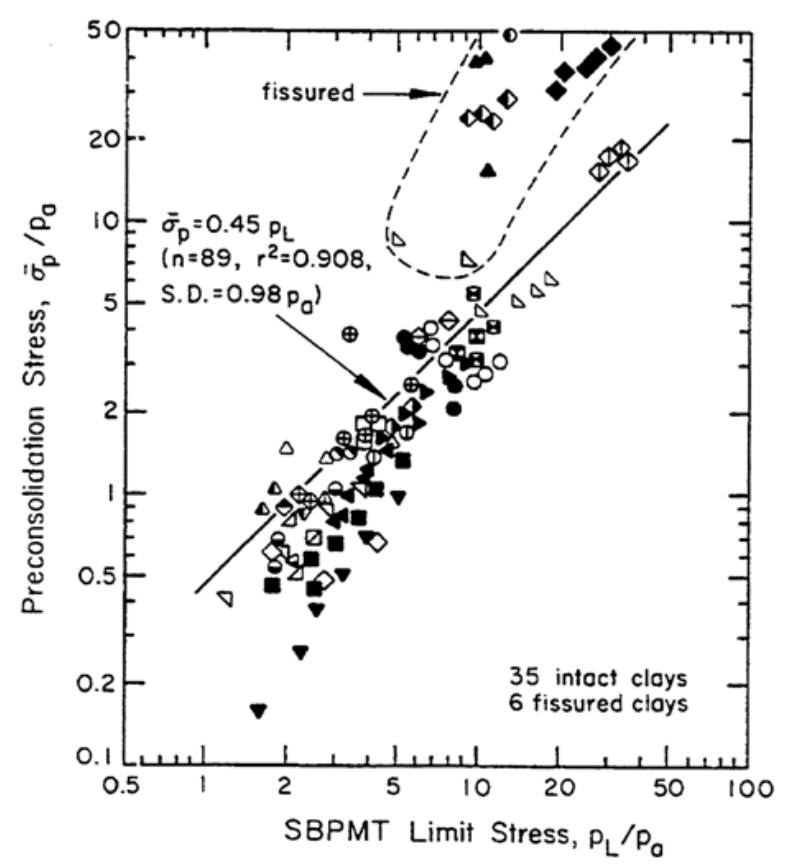

Gambar 13. Korelasi $\overline{\sigma_{p}}$ dengan limit pressure $\mathrm{p}_{\mathbf{L}}$ SBPMT (Mayne \& Kulhawy, 1988). 


\subsection{Preconsolidation Stress $\overline{\sigma_{p}}$}

Pada umumnya preconsolidation stress ditentukan dari hasil percobaan konsolidasi dilaboratorium, akan tetapi kalau contoh tanah yang dipergunakan sudah bukan undisturbed sample lagi, maka hasil yang diperoleh tentunya akan berbeda. Karenanya untuk mendapatkan hasil yang sesuai dengan keadaan yang sesungguhnya hasil uji pressuremeter dapat diharapkan memberikan hasil yang lebih mendekati hasil yang sebenarnya. Dalam perkembangan awal pressuremeter Menard diperoleh bahwa dari hasil uji pressuremeter bahwa creep pressure kurang lebih adalah sama dengan $\overline{\sigma_{p}}$ untuk tanah lempung danau daerah Chicago. Dalam penelitian selanjutnya ternyata bahwa limit presure $\left(\mathrm{p}_{\mathrm{L}}\right)$ dari self boring pressuremeter test (SBPMT) dapat dikorelasikan dengan $\overline{\sigma_{p}}$ sebagaimana diperlihatkan dalam Gambar 13 dengan persamaan :

$$
\overline{\sigma_{p}}=0.45 p_{L}
$$

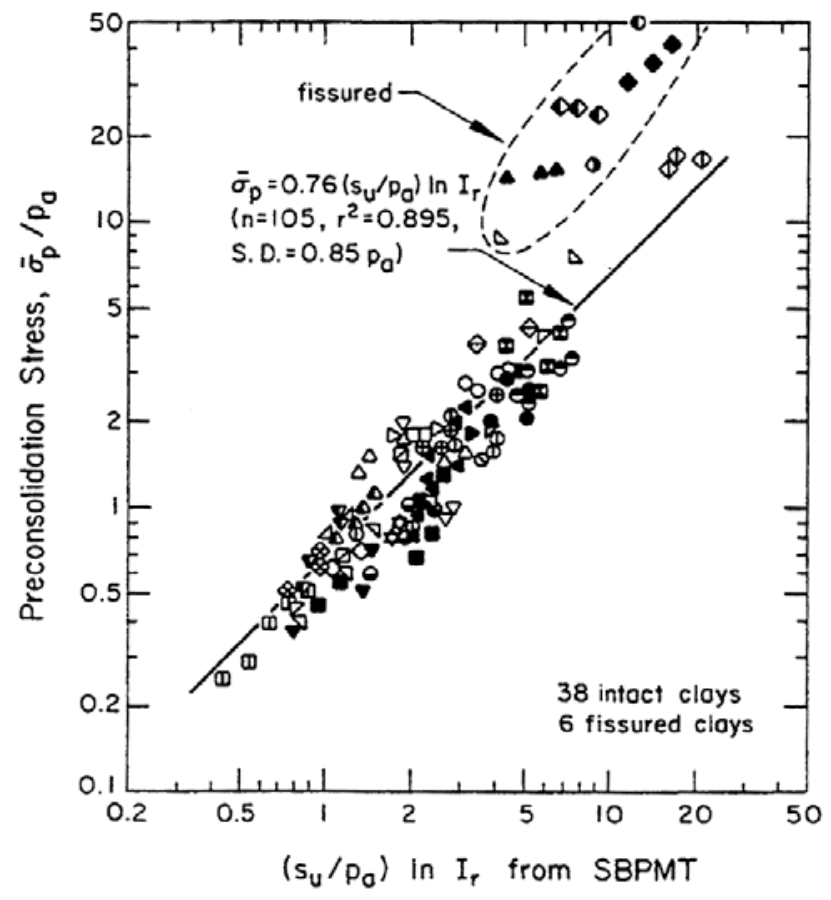

Gambar 14. Korelasi $\overline{\sigma_{p}}$ dengan $s_{u}$ dan $I_{r}$ dari SBPMT (Mayne \& Bachus,1989).

Dalam penelitian yang lain oleh Mayne \& Bachus (1989) diperoleh korelasi yang lain antara $\overline{\sigma_{p}}$ dan undrained shear strength, $\mathrm{s}_{\mathrm{u}}$ serta rigidity index, $\mathrm{I}_{\mathrm{r}}$, seperti diperlihatkan dalam Gambar 14 dengan persamaan :

$$
\overline{\sigma_{p}}=0.76\left(s_{u} / p_{a}\right) \ln I_{r}
$$




\subsection{Tegangan horizontal efektif dalam tanah kohesif}

Uji self boring pressuremeter (SBPMT) telah memperlihatkan sebagai salah satu alat uji insitu yang dapat memberikan hasil pengukuran dari tegangan horizontal efektif dilapangan secara langsung, sehingga tidak memerlukan korelasi lagi. Gambar 15 memperlihatkan hubungan antara $\mathrm{K}_{\mathrm{o}}$ (SBPMT) dan OCR dari uji oedometer. Dapat dilihat bahwa tren dari grafik pada gambar 15 konsisten dengan grafik pada gambar 16 .

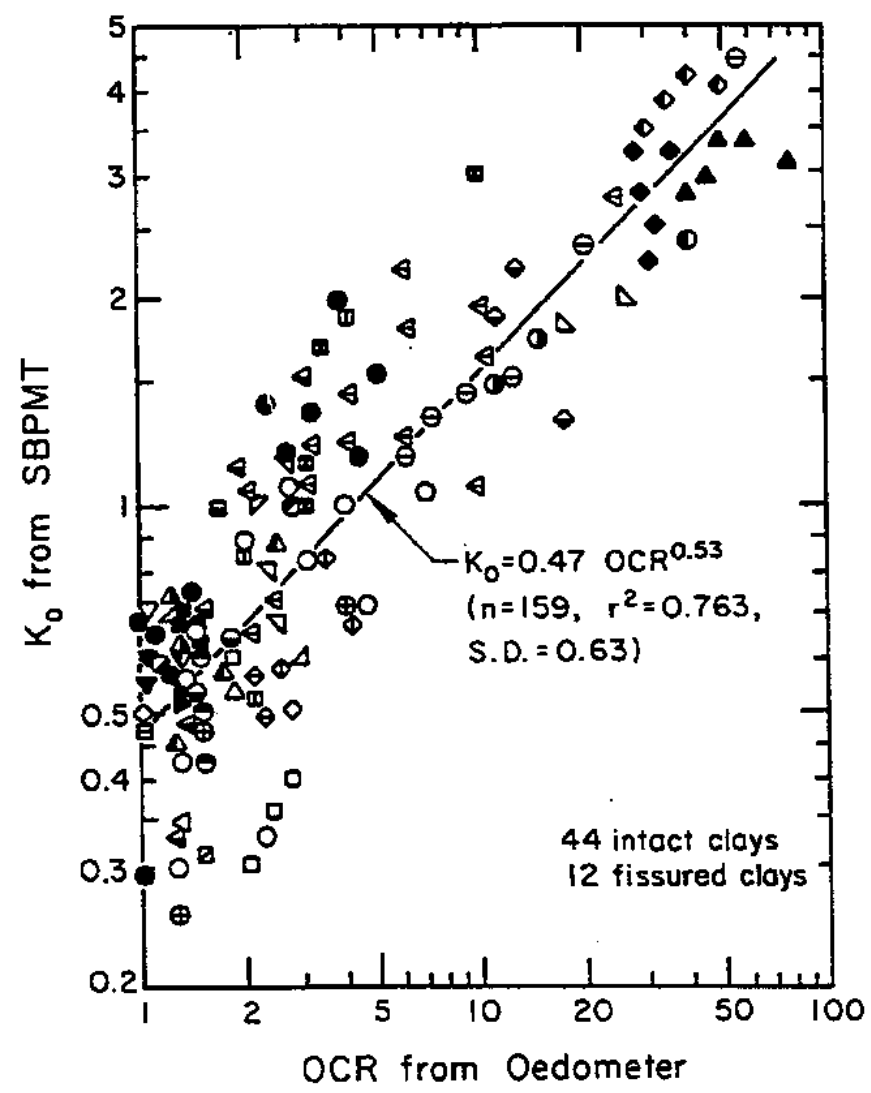

Gambar 15. Korelasi antara $\mathrm{K}_{\mathbf{0}}$ (SBPMT) dan OCR (Oedometer)

(Mayne \& Kulhawy,1988).

Hubungan antara $\mathrm{K}_{\mathrm{o}}$ (SBPMT) dan OCR dari uji oedometer dinyatakan oleh persamaan :

$$
K_{0}=0.47 O C R^{0.53}
$$

Sedangkan hubungan antara $\mathrm{K}_{0}$ dan OCR secara umum dinyatakan oleh persamaan :

$$
K_{0}=\left(1-\sin \overline{\phi_{t c}}\right) O C R^{\sin \overline{\phi_{t c}}}
$$

dimana $\overline{\phi_{t c}}$ adalah sudut $\phi$ yang diperoleh dari percobaan traksial compression. 
Mayne \& Kulhawy (1988) memberikan korelasi antara $\mathrm{K}_{0}$ dari SBPMT dan $\mathrm{K}_{\mathrm{D}}$ dari uji dilatometer (DMT) yang dinyatakan dalam persamaan :

$$
K_{0}=0.27 K_{D}
$$

dimana $\mathrm{K}_{\mathrm{D}}$ adalah horizontal stress index dari uji DMT.

Kulhawy et al (1989) memberikan korelasi antara $\mathrm{K}_{0}$ (SBPMT) dengan tahanan ujung konus yang dinormalisasi $\left(q_{T}-\sigma_{v 0}\right) / \overline{\sigma_{v 0}}$ yang dinyatakan dengan persamaan :

$$
K_{0}=0.10\left(q_{T}-\sigma_{v 0}\right) / \overline{\sigma_{v 0}}
$$

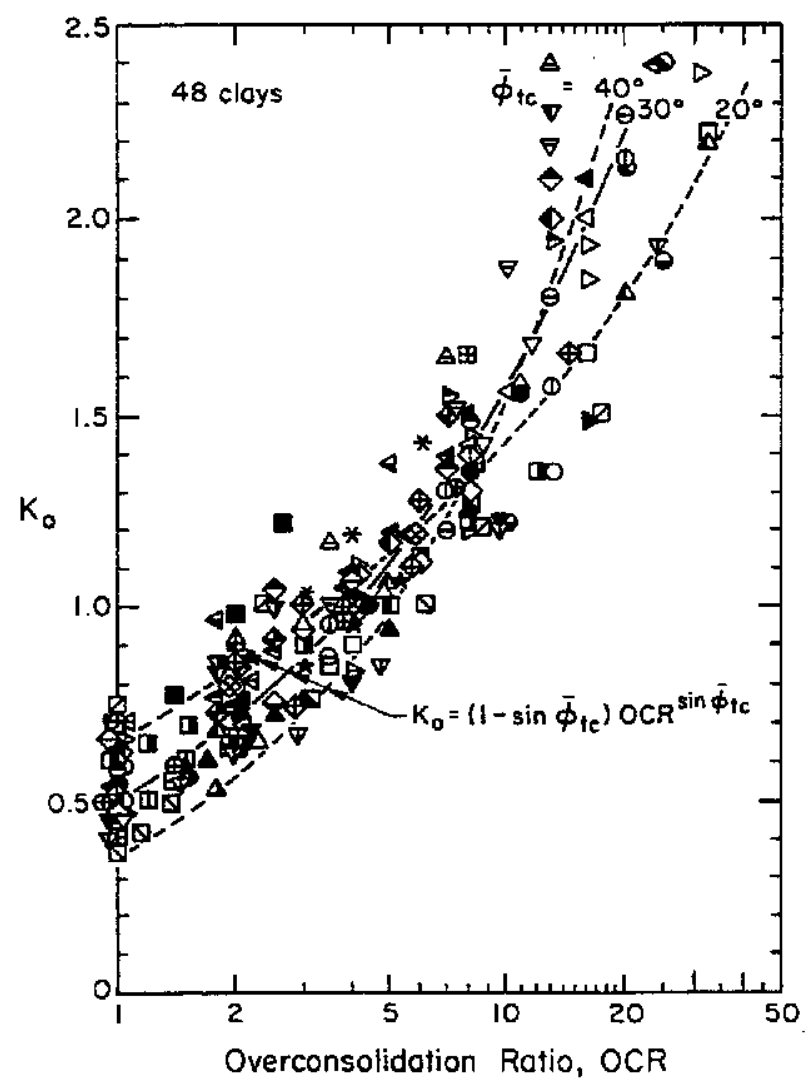

Gambar 16. Korelasi antara $K_{0}$ dan Overconsolidation Ratio (OCR)

(Mayne \& Kulhawy, 1982). 


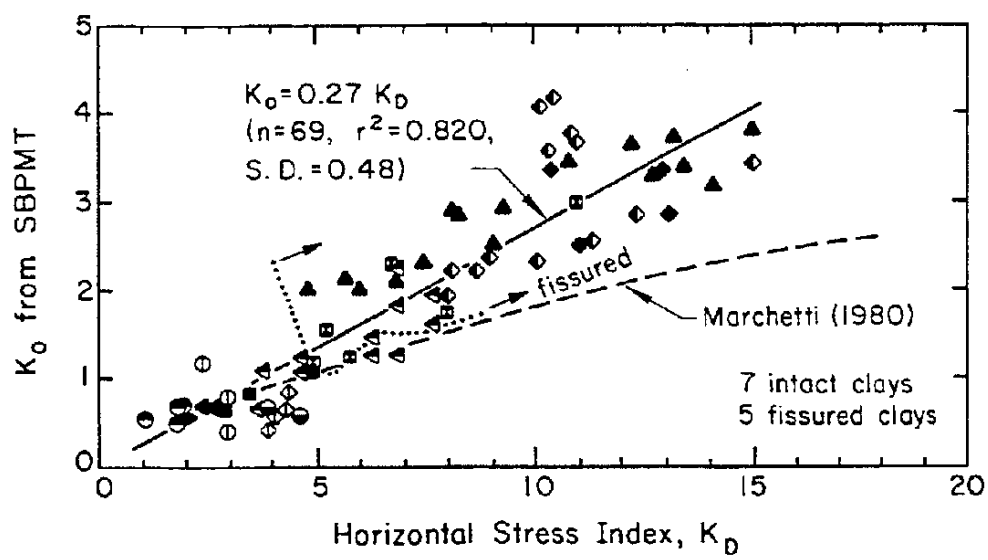

Gambar 17. Korelasi antara $K_{0}$ (SBPMT) dan $K_{D}$ (DMT)

(Mayne \& Kulhawy, 1988).

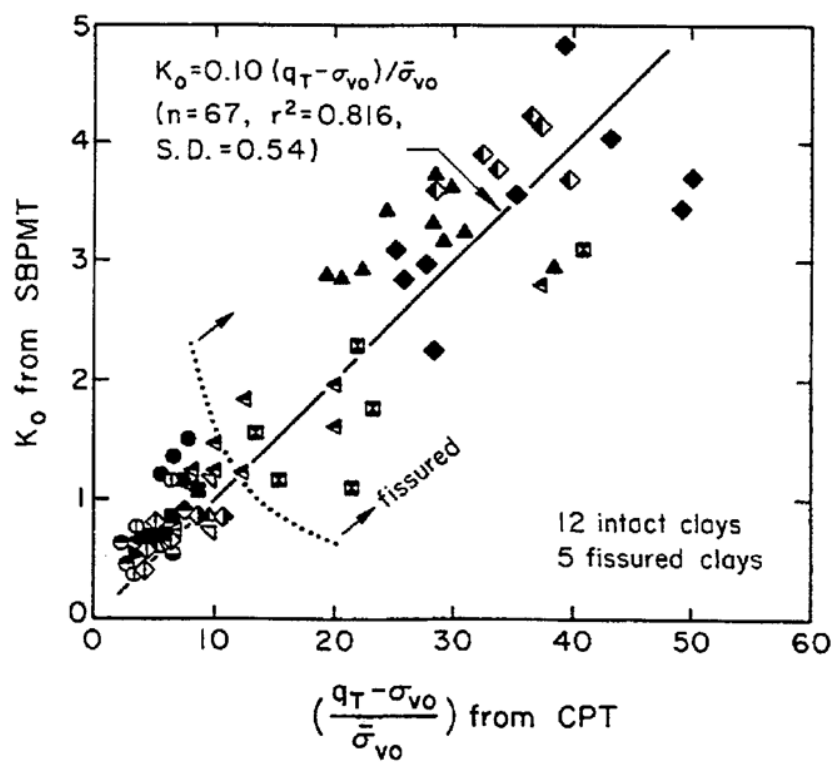

Gambar 18. Korelasi antara $K_{0}$ (SBPMT) dengan $q_{T}$ (CPTU)

(Kulhawy et al, 1989).

\subsection{KUAT GESER}

Hasil kuat geser dari hasil uji pressuremeter dapat dikorelasikan dengan sudut geser dalam efektif dengan menggunakan prosedur dari Hughes et al (1977) seperti dibawah ini. Dalam uji pressuremeter, data dasar diperoleh dari tegangan ekspansi $\left(\mathrm{p}_{\mathrm{e}}\right)$ dan perubahan volume (DV) dalam pressuremeter yang volumenya $=\mathrm{V}$. Data yang dihasilkan dapat digambarkan seperti pada Gambar 19 a dengan menggunakan regangan 
rongga $\left(\varepsilon_{c}\right.$ ) yang didefinisikan sebagai perubahan dalam radius membran dibagi dengan radius awal dan dinyatakan dengan persamaan :

$$
\varepsilon_{c}=\left(1-\varepsilon_{v}\right)^{-0.5}-1
$$
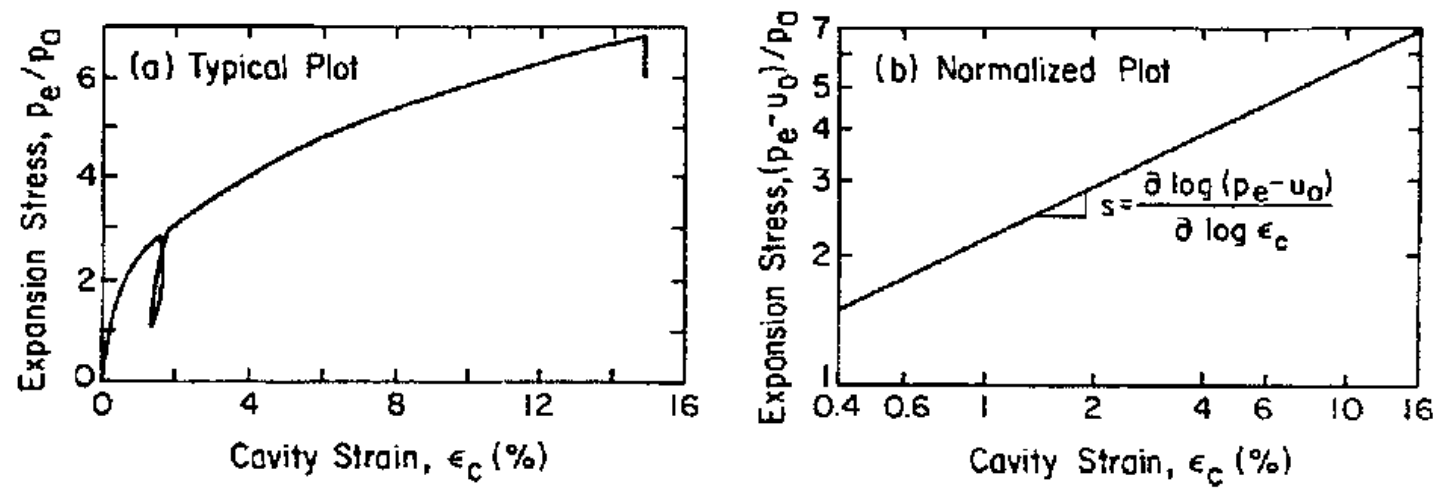

Gambar 19. Representasi data hasil uji pressueremeter (Mair dan Wood, 1987).

Dimana $\varepsilon_{V}=\Delta V / V=$ regangan volume. Data ini kemudian diplotkan kembali seperti pada Gambar 19 b dengan mengurangi tegangan pori awal pada permukaan pressuremeter.

Hasil penggambaran dalam skala log-log pada dasarnya adalah linier dengan kemiringan $s$. Dengan mempertimbangkan teori pengembangan rongga silinder, maka persamaan garis s sebagai berikut :

$$
s=\sin \overline{\phi_{c v}}(1+\sin \psi) / \sin \overline{\phi_{c v}}
$$

Dimana $\overline{\phi_{c v}}=$ sudut geser pada kadar pori kritis dan $\psi=$ sudut dilasi $\left(\overline{\phi_{t c}}-\overline{\phi_{c v}}\right)$. Persamaan (26) dapat disusun kembali menjadi :

$$
\sin \psi=s\left(1+\sin \overline{\phi_{c v}}\right) / \sin \overline{\phi_{c v}}
$$

Karenanya, dengan menggambarkan kembali data presuremeter akan menghasilkan $\mathrm{s}$ dan memperkirakan $\overline{\phi_{c v}}$ sebagaimana dijelaskan sebelumnya, sudut geser $\overline{\phi_{t c}}$ dapat diperoleh. Dari Gambar 20, $\overline{\phi_{t c}}$ dapat diperoleh dengan menggunakan pendekatan dari Bolton (1986) sebagai berikut :

$$
\overline{\phi_{t c}}=\overline{\phi_{c v}}+0.8 \phi
$$

Secara empiris undrained shear strength dapat dihitung berdasarkan model elasto plastis untuk perilaku tanah dengan menggunakan persamaan untuk tegangan horizontal dilapangan, $\mathrm{p}_{0 \mathrm{~h}}$ sebagai berikut : 


$$
p_{0 h}=p_{L}-N_{p} S_{u}
$$

dimana : $\quad \mathrm{p}_{\mathrm{L}} \quad=$ tekanan batas dari Menard

$\mathrm{S}_{\mathrm{u}} \quad=$ undrained shear strength

$\mathrm{N}_{\mathrm{p}} \quad=$ faktor empiris $=N_{p}=1+\ln \frac{E_{u}}{3 S_{u}}$

$\mathrm{E}_{\mathrm{u}} \quad=$ undrained Young modulus

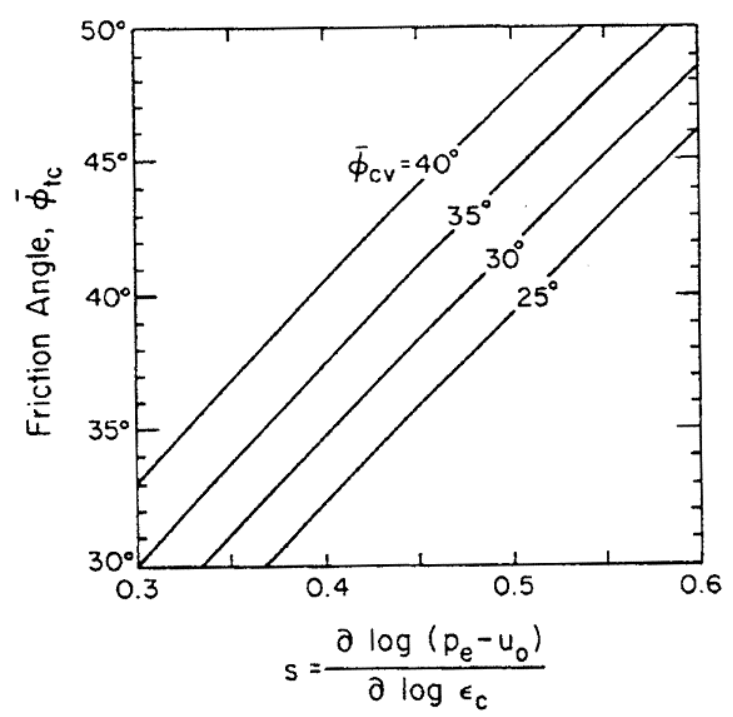

Gambar 20. Evaluasi sudut geser dari uji pressuremeter ( Mair dan Wood, 1987).

Kuat geser tak terdrainasi puncak (peak undrained shear strength) dari tanah lempung dapat ditentukan juga dari kurva pressuremeter seperti diperlihatkan pada Gambar 21 dengan menggunakan metode dari Palmer (1972). Dalam gambar tadi diperlihatkan proses untuk menentukan shear stress.

Bergado \& Khaleque (1986) memberikan korelasi untuk tegangan geser tak terdrainasi yang diperoleh dari LLT presuremeter dibandingkan dengan yang diperoleh dari uji coba geser baling-baling dan dari uji konus Belanda khusus untuk tanah lempung Bangkok yang lunak dan teguh sebagai berikut :

$>$ Lempung Bangkok lunak kedalaman 2 sampai 9 meter :

$$
\begin{aligned}
& \mathrm{S}_{\mathrm{uv}}=\mathrm{S}_{\mathrm{up}} / 1.20 \\
& \mathrm{~S}_{\mathrm{uv}}=\mathrm{P}_{\mathrm{y}} / 3.15=\mathrm{P}_{\mathrm{L}} / 5.90 \\
& \mathrm{~S}_{\mathrm{up}}=\mathrm{q}_{\mathrm{c}} / 16.4=\mathrm{f}_{\mathrm{s}} / 0.61
\end{aligned}
$$

$>$ Lempung Bangkok teguh kedalaman 9 sampai 15 meter: 


$$
\mathrm{S}_{\mathrm{up}}=\mathrm{q}_{\mathrm{c}} / 19.4=\mathrm{f}_{\mathrm{s}} / 0.53
$$

dimana :

$\mathrm{S}_{\mathrm{uv}} \quad$ : undrained shear strength dari uji geser baling-baling

$\mathrm{S}_{\mathrm{up}} \quad$ : undrained shear strength dari uji pressuremeter

$\mathrm{P}_{\mathrm{y}} \quad$ : tegangan rangkak

$\mathrm{P}_{\mathrm{L}} \quad$ : tegangan batas

$\mathrm{q}_{\mathrm{c}} \quad$ : tahanan konus

$\mathrm{f}_{\mathrm{s}} \quad$ : gesekan lokal

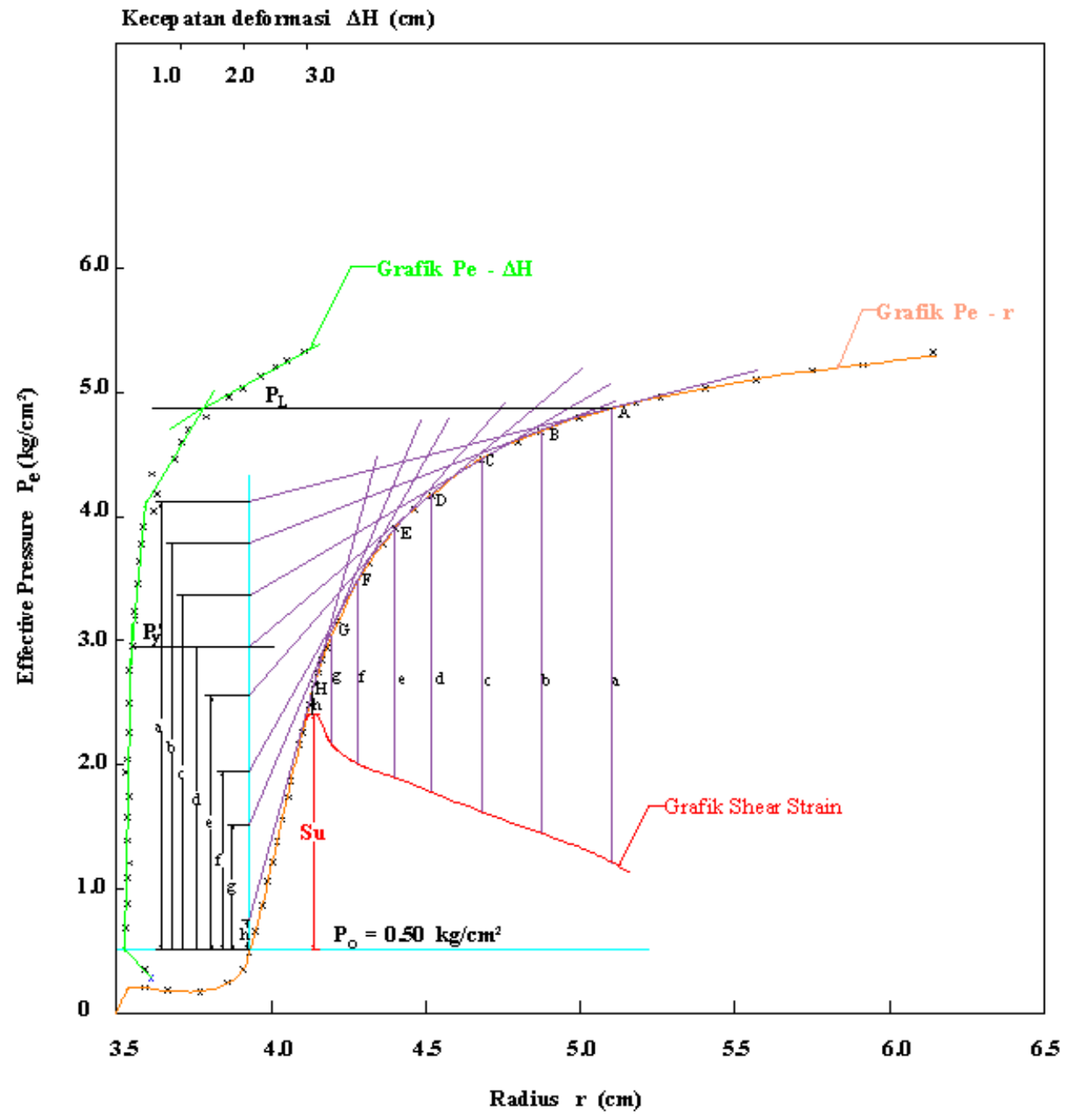

Gambar 21. Penentuan undrained shear strength dari LLT secara grafis (Palmer 1972).

Imai dan Konno (1976) memberikan hubungan antara Specific $K$ value $\left(\mathrm{k}_{\mathrm{o}}\right)$ dengan unconfined compresive strength (gambar 22a); Deformation Coefficient $\left(\mathrm{E}_{\mathrm{L}}\right)$ 
dengan unconfined compresive strength (gambar 22b); serta Yield Pressure $\left(\mathrm{P}_{\mathrm{YL}}\right)$ dengan unconfined compresive strength (gambar 22c).

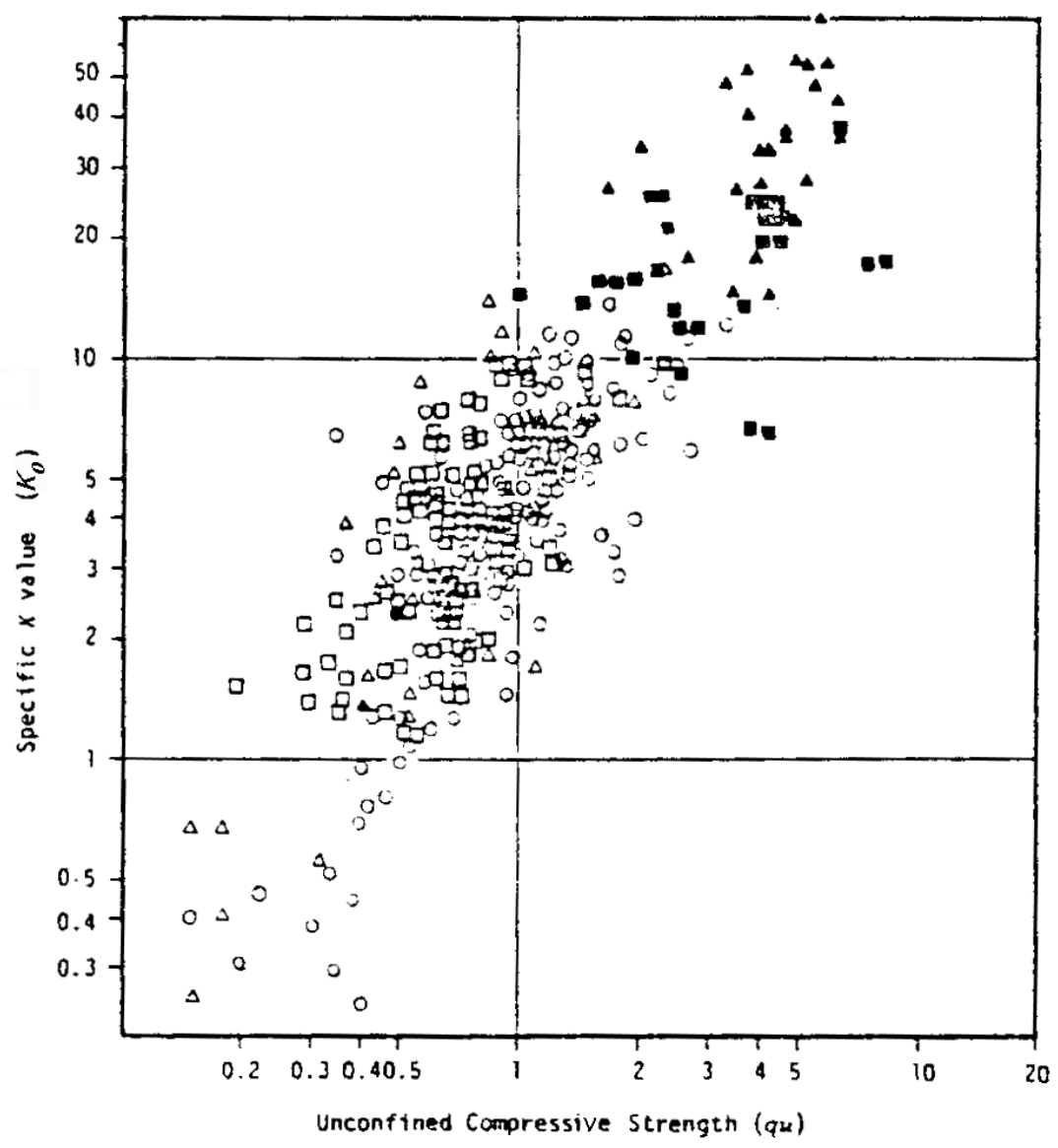

(a). Hubungan antara Specific K value $\left(\mathrm{k}_{0}\right)$ dengan unconfined compresive strength.

Gambar 22. Tinjauan Pustaka (Imai, 1977). 


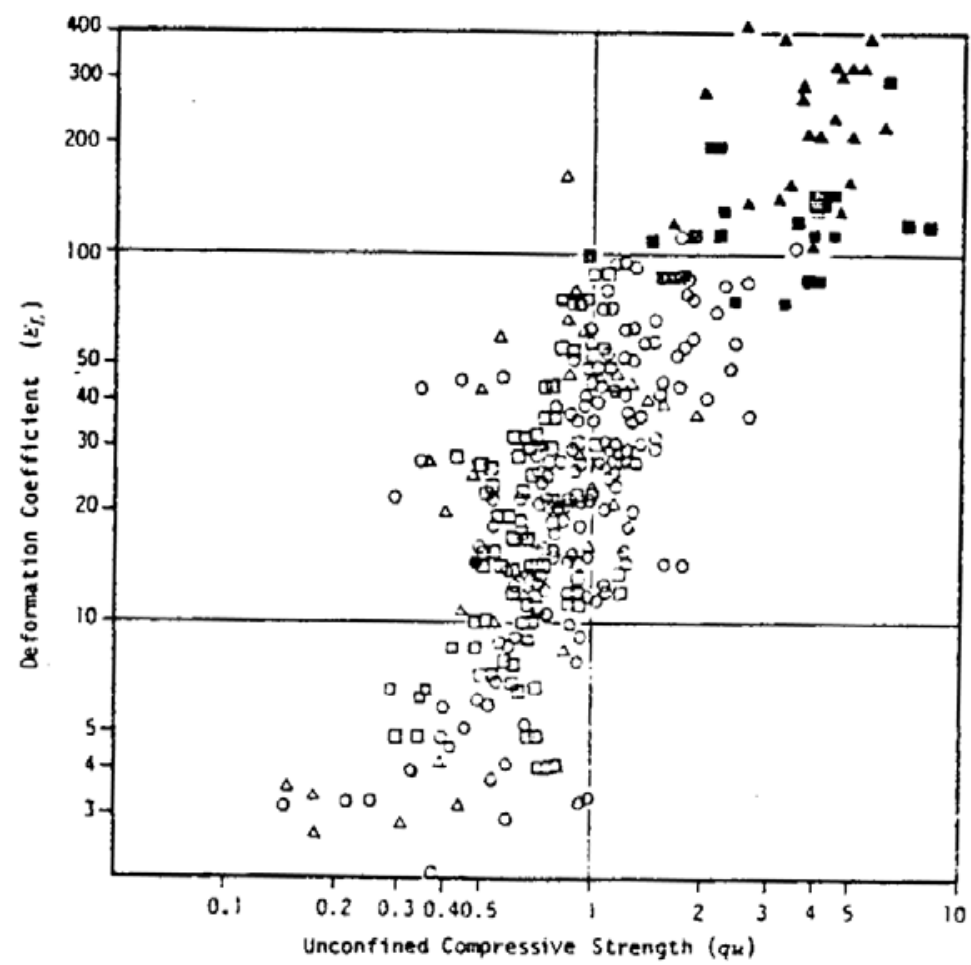

(b). Hubungan antara Deformation Coefficient $\left(\mathrm{E}_{\mathrm{L}}\right)$ dengan unconfined compresive strength.

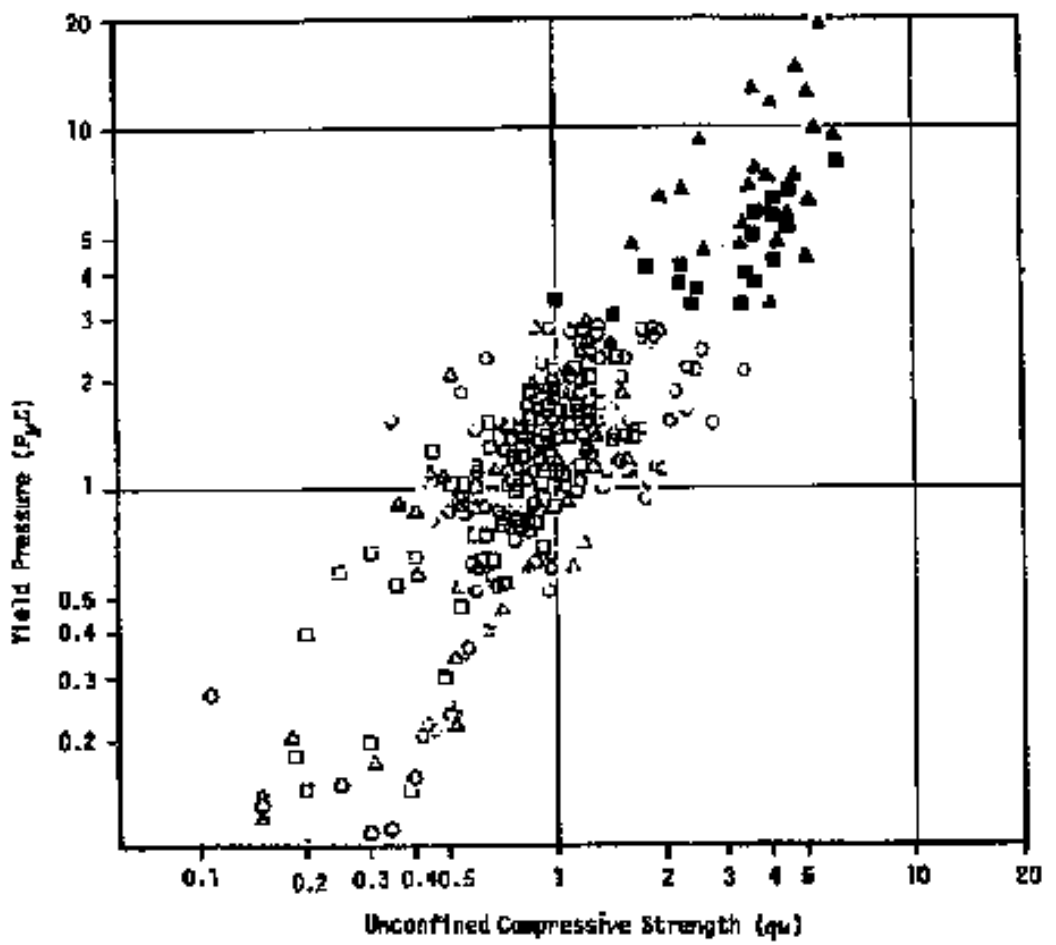

(c). Hubungan antara Yield Pressure $\left(\mathrm{P}_{\mathrm{YL}}\right)$ dengan unconfined compresive strength.

Gambar 22. Tinjauan Pustaka (Imai, 1977) (lanjutan). 


\section{MODULUS PRESSUREMETER}

Modulus pressuremeter dari Menard adalah parameter yang diambil secara langsung dari hasil uji presuremeter dan juga merupakan satu-satunya uji tanah in situ yang menghasilkan modulus tanah. Modulus Menard atau modulus pressuremeter adalah modulus elastis awal dari kemiringan garis $\mathrm{AB}$ pada Gambar 1 yang dikenal dari creep curve sebagai batas yang memberikan respon elastis. Kemiringan $\mathrm{AB}$ adalah fungsi dari modulus geser dan menghasilkan modulus Menard, $E_{m}$ sebagai berikut :

$$
E_{m}=2.66\left[V_{o}+0.5\left(V_{B}-V_{A}\right)\right]\left(\frac{p_{A}-p_{B}}{V_{A}-V_{B}}\right)
$$

dimana $V_{o}$ adalah volume probe, $V_{A}$ adalah volume pada tekanan $p_{A}$ dan $V_{B}$ adalah volume pada tekanan $\mathrm{p}_{\mathrm{B}}$. Faktor 2.66 berdasarkan anggapan bahwa rasio Poisson adalah 0.33. Standar ASTM juga memberikan rumus yang sama tetapi mengijinkan penggunaan nilai rasio Poisson selain dari 0.33 .

Uji pressuremeter memberikan suatu pengukuran untuk modulus horizontal dalam tanah. Dalam lempung, dianggap bahwa $E_{P M T}=E_{u}$. Untuk penggunaan secara praktis telah dicoba mengkorelasikan $\mathrm{E}_{\mathrm{PMT}}$ dengan nilai $\mathrm{N}$ dari SPT, sebagaimana diperlihatkan dalam Gambar 23 dibawah ini.

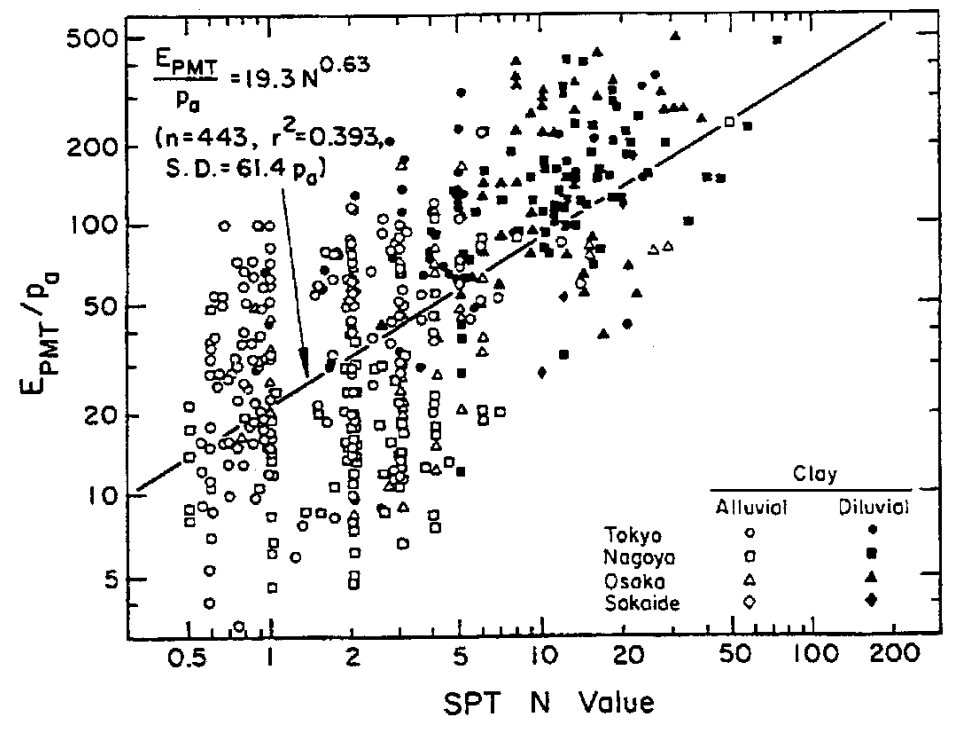

Gambar 23. Modulus PMT dari lempung versus Nilai N SPT (Ohya et al, 1982).

Untuk tanah berbutir kasar dianggap $\mathrm{E}_{\mathrm{PMT}}$ kurang lebih sama modulus Young E. Korelasi

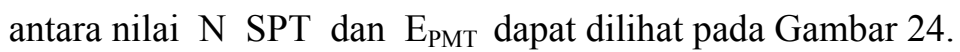




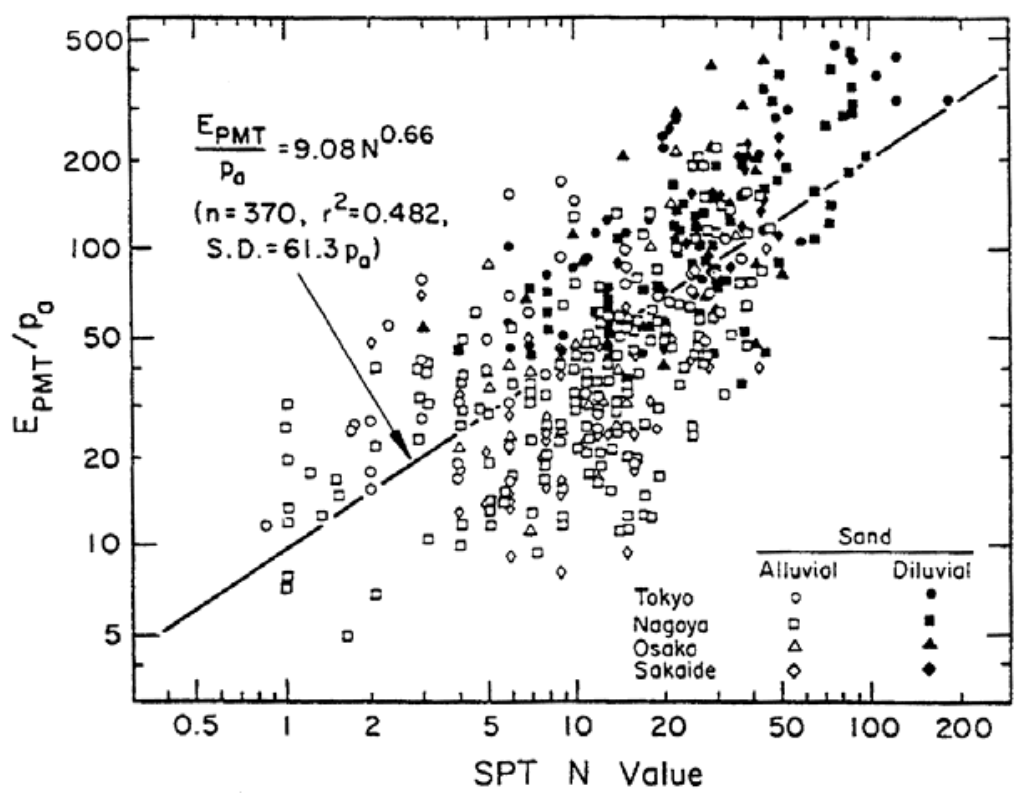

Gambar 24. Modulus PMT dari pasir versus nilai N SPT ( Ohya et al, 1982).

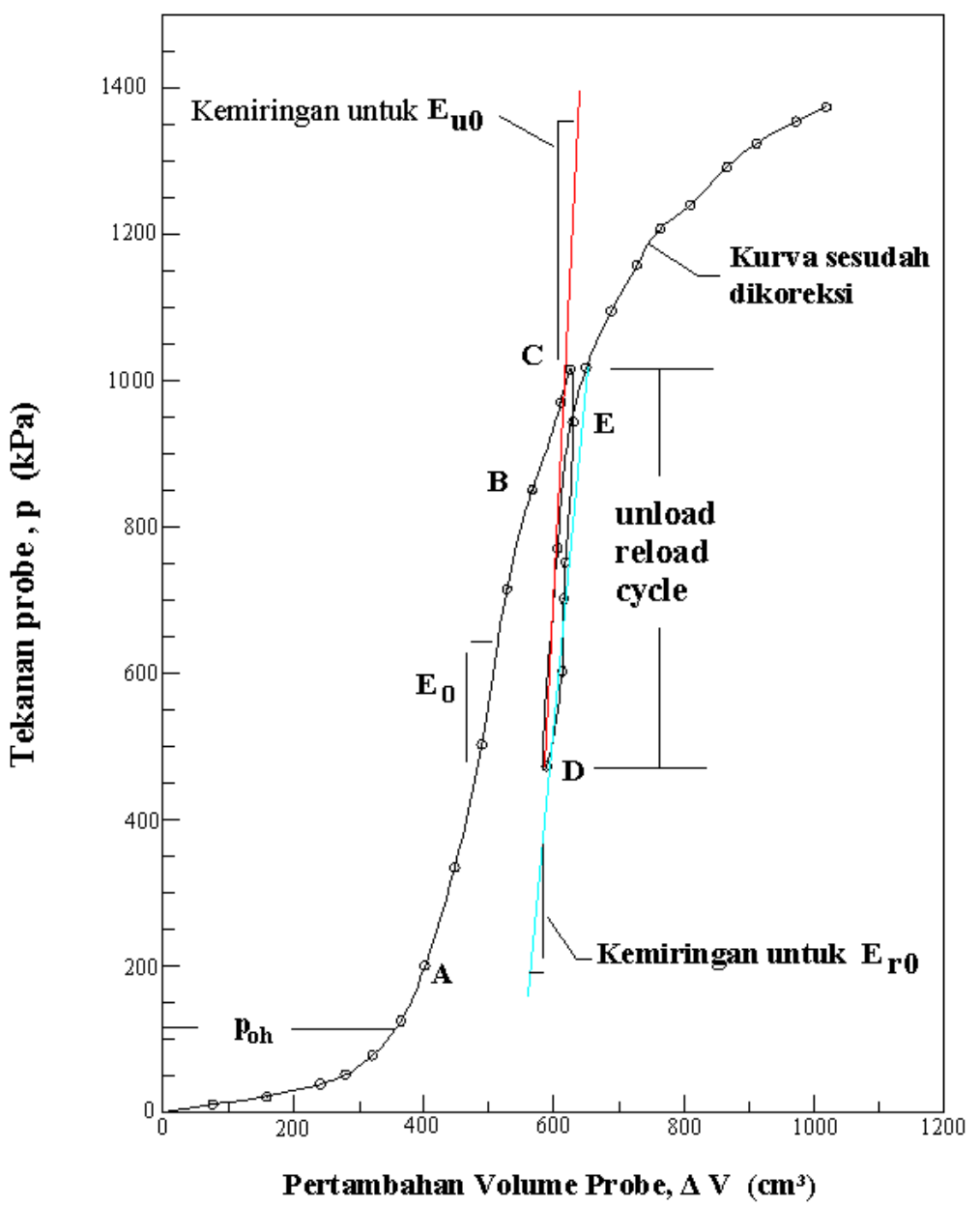

Gambar 25. Penggambaran hasil uji Menard Pressuremeter dengan unload dan reload cycle (Briaud et al, 1983). 
Dari Gambar 25, modulus geser $\mathrm{G}$ dapat dihitung dari rumus :

$$
G=\frac{E}{2(1+v)}
$$

Dibawah ini diberikan hasil pengujian pressuremeter dengan unloading - reloading cycle untuk tanah lempung dan tanah pasir.

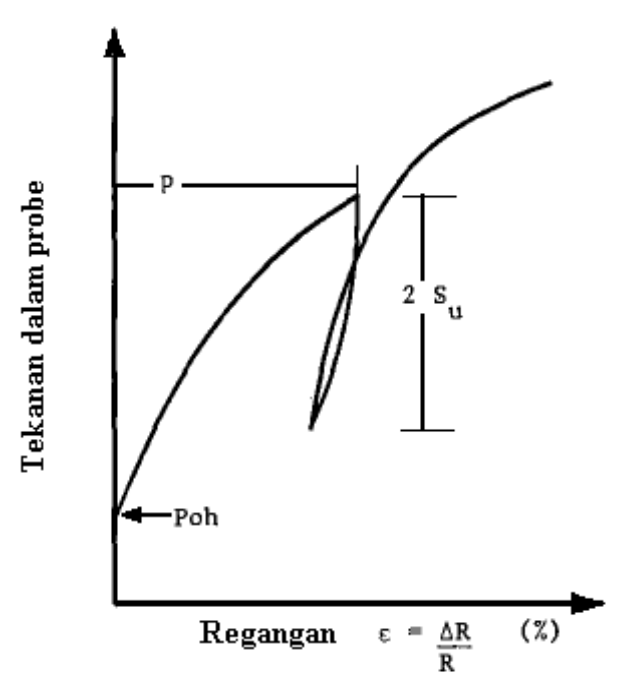

a) Lempung

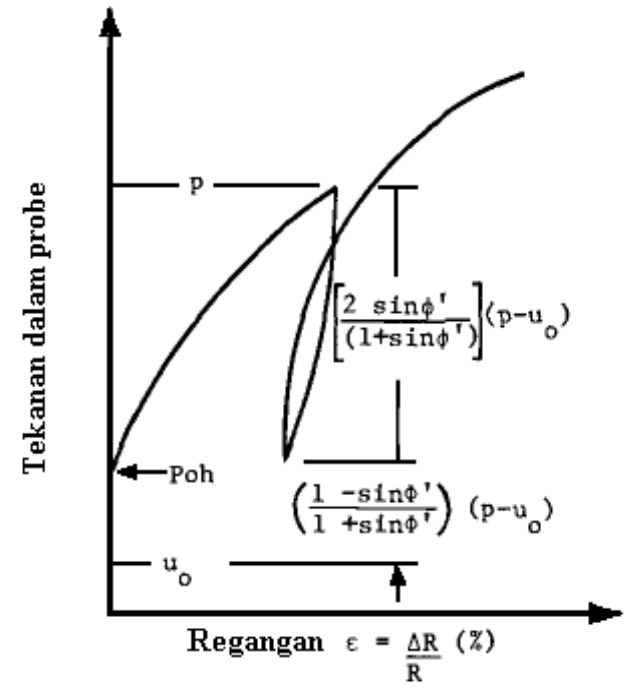

b) Pasir

Gambar 26. Hasil uji pressuremeter dengan unloading-reloading cycle untuk (a) lempung dan (b) pasir (Briaud, 1992).

Combarieu dan Canepa (2001) dari hasil uji pressuremeter dengan unload-reload mendapatkan rasio $\mathrm{E}_{\mathrm{r}} / \mathrm{E}_{\mathrm{M}}$ dan $\mathrm{E}_{\mathrm{r}} / \mathrm{p}_{\mathrm{L}}$ untuk berbagai jenis tanah sebagai berikut :

Tabel 8. Rasio $E_{\mathrm{r}} / \mathbf{E}_{\mathrm{M}}$ dan $\mathrm{E}_{\mathrm{r}} / \mathbf{p}_{\mathrm{L}}$ dari hasil uji pressuremeter dengan unload dan reload (Combarieu \& Canepa, 2001).

\begin{tabular}{|l|l|l|}
\hline \multicolumn{1}{|c|}{ Jenis tanah } & \multicolumn{1}{c|}{$\mathbf{E}_{\mathbf{r}} / \mathbf{E}_{\mathbf{M}}$} & \multicolumn{1}{c|}{$\mathbf{E}_{\mathbf{r}} / \mathbf{p}_{\mathbf{L}}$} \\
\hline Stiff overconsolidated clay & $2.5-3.5$ & $25-45$ \\
\hline Silt & $3-4.5$ & $35-45$ \\
\hline Sand & $6-7.5$ & $35-80$ \\
\hline Chalk & 5.5 & 80 \\
\hline
\end{tabular}

dimana $: \mathrm{E}_{\mathrm{r}}=\mathrm{E}$ reload $; \mathrm{E}_{\mathrm{M}}=$ modulus Menard; $\mathrm{p}_{\mathrm{L}}=$ tegangan batas (limit pressure) 


\section{KESIMPULAN}

1. Penggunaan hasil uji pressuremeter secara langsung dalam perancangan merupakan metode yang banyak sekali digunakan berdasarkan pada filosofi bahwa perilaku pondasi dalam skala penuh dapat dihubungkan dengan parameter yang diperoleh dari korelasi empiris berdasarkan teori.

2. Sebagai alternatif, metode tidak langsung adalah metode untuk menganalisa suatu pengujian untuk menghasilkan parameter yang mewakili perilaku tanah. Parameter yang yang diperoleh adalah fungsi dari pelaksanaan pengujian dan prosedur pengujian dan metode interpretasi, sehingga sangat penting untuk mengikuti prosedur standar selama memungkinkan untuk membakukan dampak dari pelaksanaan dilapangan.

3. Dalam tulisan ini dilampirkan juga korelasi antara parameter tanah yang diperoleh dari pengujian pressuremeter dibandingkan dengan hasi dari pengujian Standard Penetration Test (SPT), Cone Penetration Test (CPT), Dilatometer Test (DMT), Unconfined Compression Test dan dari Oedometer Test.

4. Uji pressuremeter sangat bermanfaat khususnya untuk parameter tanah lempung yang mempunyai riwayat konsolidasi berlebih (over consolidated clay).

\section{DAFTAR PUSTAKA}

1. Baguelin, F., Jezequel, J.F., dan Shields, D.H. 1978. The pressuremeter and foundation engineering. Trans Tech Publications, Clausthall, Germany, 278 pp.

2. Bergado, D.T. dan Khaleque M.A. 1986. Correlations of LLT Pressuremeter, vane, and dutch cone tests in Bangkok marine clay, Thailand. The pressuremeter and its marine applications: second international symposium , ASTM STP 950. American Society of Civil Engineers.

3. Bolton, M.D. 1986. The strength and dilatancy of sands. Geotehnique. Vol. 19. No.1, March, pp. 65 - 86.

4. Briaud, J.L. 1992. The pressuremeter. AA Balkema Publishers, The Netherlands, $192 \mathrm{pp}$.

5. Briaud, J.-L., Tucker, L., and F e 1 i o , G.Y. 1983. Pressuremeter, Cone penetrometer and foundation design. Short course notes. Vol.1, Texas A\&M University, College Station, Texas.

6. Bustamante, M. dan Frank, R. 1999. Current French practice for axially loaded piles. Ground Engineering, March, 38 - 44.

7. Clarke, B.G. 1995. Pressuremeter in Geotechnical Design. Chapman \& Hall. 
London

8. Combarieu O. dan Canepa Y. 2001. The unload-reload pressuremeter test.Bulletin des laboratoires des ponts et chaussees. 233-July-August 2001-Ref.4381-pp 3767. Paris

9. Cone Penetrometer, and Foundation Design. Short Course Notes, Eurocode 7 , 2004 : Geotechnical design- General rules. Designers Guide to EN 1997 - 1. Thomas Telford.London

10. Eurocode 7, 2004 : Geotechnical design-General rules. Designers Guide to EN 1997 - 1. Thomas Telford.London

11. Felio, G.Y. dan Briaud, J.L. 1986. Conventional parameters from pressuremeter test data : Review of existing methods. The pressuremeter and its marine applications, Second international symposium STP 950.J.L.Briaud and J.M.E.Audiberts, Eds.American Society for Testing and Materials.

12. Frank, R. 1999.Calculated response of shallow and deep foundations.Techniques de l'Ingenieur (TI) et Presses de l'Ecole nationale des ponts et chaussees, 2eme trimestre, 139 pp, in French.

13. Frank, R. dan Zhao, M. 1982. Prediction of parameters from pressuremeter tests and their applications to pile design in fine soils. Bulletin des Laboratories des Ponts et Chaussees, Paris, $119: 17$-24, in French

14. Gambin, M. 1963. Prediction of pile settlement from pressuremeter tests. SolsSoils, 7.

15. Hughes, J.M.O., Wroth, C.P., dan Windle, D. 1977. Pressuremeter tests in sands, Geotechnique, Vol. 27, No. 4, December, pp. 445 -477

16. Imai, M. 1977. Study of subgrade reaction coefficient K value. OYO Technical Note

17. Imai, T dan Konno, M. 1976 . Relations between LLT measurement results and soil engineering properties. OYO technical note.Studies of soil reaction coefficient K-value of soil ground.OYO Corporation, Tokyo, Japan.

18. Kaczyynski R.R. 2008. Formation of engineering properties of soils during geological history. Geologija,Vol.50, Supplement P. S4-S-10.Vilnius.Poland

19. Kulhawy, F.H., Jackson, C.S. dan Mayne, P.W. 1989. First order estimation of $\mathrm{K}_{0}$ in sands and clays, Foundation Engineering current principles and practices, Ed.F.H. Kulhawy, ASCE, New York, pp. 121 - 134 
20. Mair, R.J. dan Wood, D.M. 1987. Pressuremeter testing. Butterworths, London.

21. Mayne, P.W. dan Bachus, R.C., 1989. Penetration pore pressures in clay from CPTU, DMT, dan SBP, Proceedings, 12th International Conference on Soil Mechanics and Foundation Engineeering. Vol. 1 , Rio de Janeiro, 1989, pp. 291 $-294$.

22. Mayne, P.W. dan Kulhawy, F.H. 1988. Discusion of independence of geostatic stress from overconsolidation in some Beaufort Sea Clays. Canadian Geotechnical Journal, Vol. 25, No.3,Aug. 1988, pp. 617-621

23. Mayne, P.W. dan Kulhawy, F.H. 1990. Manual on estimating soil properties for foundation design.Electric Power Institute.EPRI EL-6800.Cornell University, Ithaca, New York.

24. Menard, L. dan Rousseau, J.1962.Evaluation of settlements: tendencies. Solssoils, 1 , in French.

25. Ohya, S., Imai ,T. dan Matsubara, M. 1982. Relationships between N value by SPT and LLT Pressuremeter results, Proceedings, 2nd European Symposium on penetration testing, volume1.Amsterdam, pp.125-130

26. Palmer, A.C. 1972. Undrained plane strain expansion of a cylindrical cavity in clay; A simple interpretation of the pressuremeter test. Geotechnique, Vol. 22 , no.3.

27. Schmertmann J.H. 1985. Measure and use of the insitu lateral stress. The practice of foundation engineering. A volume honoring Jorj O. Osterberg. The department of civil engineering, Northwestern University.

28. Schnaid, F. 2005. Geocharacterization and properties of natural soils by in situ tests. State of the art report. Proc. 16 th International Conference on Soil Mechanics and Geotechnical Engineering (ICSMGE), Osaka, $1: 3$ - 46.

29. Schnaid, F. 2009. In situ testing in geomechanics. Taylor \& Francis. London

30. Yoshii, R.1979. Comparative trial of lateral load testers. Short course on engineering geology. Asian Institute of Technology, Bangkok, Thailand. 